\title{
Spatial variations in biomarkers of Mytilus edulis mussels at four polluted regions spanning the Northern Hemisphere
}

\author{
F. Gagné ${ }^{a,{ }^{*}}$, T. Burgeot ${ }^{b}$, J. Hellou ${ }^{c}$, S. St-Jean ${ }^{d}$, É. Farcy $^{b}$ and C. Blaise ${ }^{a}$
}

\author{
a Fluvial Ecosystem Research, Environment Canada, 105 McGill Street, Montréal, Qué., Canada H2Y 2E7 \\ ${ }^{\mathrm{b}}$ IFREMER, Département Biogéochimie et Écotoxicologie, BP 2110544311 Nantes cedex 03, France \\ ${ }^{c}$ Marine Environmental Science, Bedford Institute of Oceanography, Fisheries and Oceans Canada, Dartmouth, \\ Nova Scotia, Canada B2Y 4A2 \\ d Jacques Whitford Consultants, 3 Spectacle Lake Drive, Dartmouth, Nova Scotia, Canada B3B 1W8 \\ *: Corresponding author : Gagné F., email address : Francois.Gagne@ec.gc.ca
}

\begin{abstract}
:
Economic and social developments have taken place at the expense of the health of the environment, both locally and on a global scale. In an attempt to better understand the large-scale effects of pollution and other stressors like climate change on the health status of Mytilus edulis, mussels were collected during the first two weeks of June 2005 at three sites (one pristine and two affected by pollution) located in each of the regions of the Canadian West Coast, the St. Lawrence estuary, the Atlantic East Coast and the northwestern coast of France, covering a total distance of some 11000 $\mathrm{km}$. The mussels were analyzed for morphologic integrity (condition factor), gametogenic activity (gonado-somatic and gonad maturation index, vitellogenin(Vtg)-like proteins), energy status (temperature-dependent mitochondrial electron transport activity and gonad lipid stores), defense mechanisms (glutathione S-transferase, metallothioneins, cytochrome P4503A activity and xanthine oxidoreductase-XOR), and tissue damage (lipid peroxidation-LPO and DNA strand breaks). The results showed that data from the reference sites in each region were usually not normally distributed, with discriminant factors reaching the number of regions (i.e. four), except for the biomarkers gonadal lipids, XOR and LPO in digestive gland. The integrated responses of the biomarkers revealed that biomarkers of stress were significantly more pronounced in mussels from the Seine estuary, suggesting that the impacts of pollution are more generalized in this area. Mussels from the Seine estuary and the Atlantic East Coast (Halifax Harbor) responded more strongly for Vtg-like proteins, but was not related to gonad maturation and gonado-somatic indexes, suggesting the presence of environmental estrogens. Moreover, these mussels displayed reduced DNA repair activity and increased LPO. Factorial analyses revealed that energy status, cytochrome P4503A activity and Vtglike proteins were the most important biomarkers. Adaptation to warmer temperatures was reflected at the energy status levels, mussels from both the polluted and warmer sites displaying increased ratios of mitochondrial activity to lipid stores. Regional observations of biomarkers of energy status, gametogenesis and pollutant-related effects were influenced by nutrition, oxygen availability (eutrophication), and thermal history.
\end{abstract}

Keywords: Biomarkers; Pollution; Global changes; Mytilus edulis; Health status

\section{Introduction}

The realization that anthropogenic activity affects the quality of ecosystems locally and globally has given impetus to the issue of examining pollution effects from a more holistic perspective. Indeed, pollution is just a part-albeit one of particular consequence, in some cases-of the various stressors that accumulate to the point of compromising ecosystem health (Vasseur and Cossu-Leguille, 2006). These stressors are sometimes referred to as "confounding" environmental variables (e.g. physical and chemical habitat 
characteristics, prey-predation pressures, and climate change) that can influence the susceptibility of organisms to contaminants. For example, inconsistent changes in biomass in local mussel populations have suggested that other and much larger processes such as global warming were at stake (Smith et al., 2006). As a particular case of these large-scale processes, the cumulative impacts of global warming in the context of pollution stress are intriguing. In a recent study, the sensitivity of mitochondrial electron transport to temperature increments was enhanced, suggesting that organisms from polluted environments expend much more energy (in terms of mitochondrial electron transport activity) when temperatures rise (Gagné et al., 2007a). Moreover, the balance between energy stored in the form of lipids and mitochrondrial electron activity in clams exposed to warmer, polluted environments made it possible for us to consider adaptative mechanisms to temperature and pollution exposure. At pollution-impacted sites and sites adapted to warmer temperatures, the energy budget (ratio of mitochondrial activity to lipid levels) was significantly higher than at sites adapted to cold temperatures, indicating that habitat warming depletes energy stores and enhances energy expenditures in bivalves. However, studies of pollution effects that encompass processes occurring at larger scales such as temperature variation and habitat changes (e.g. different marine systems) are lacking at present, thereby compromising risk assessment processes at a time of global warming. This study sought to examine the challenges implicated in assessing various biomarkers of toxic stress in mussels collected at selected sites spanning the Pacific to the Atlantic oceans in the Northern Hemisphere. 
Intertidal blue mussels (Mytilus edilus) are of their commercial importance as a recognized nutritive choice, but are also known for their role in marine ecosystems and ubiquity in the Northern Hemisphere. The species was selected for this study because of its global distribution, its longevity and its sessile behavior. Mussel health status was examined using a comprehensive suite of physiological biomarkers to assess morphological characteristics, gametogenic activity, energy allocation, biomarkers of defense mechanisms and biomarkers of toxic stress. Gametogenic activity was tracked by determining the gonado-somatic index, gonad maturation index and levels of vitellogenin-like proteins. Pollution was shown to alter gamete development and influence levels of the egg-yolk vitellogenins (Vtg) in the blue mussel Mytilus edulis and the soft-shell clam Mya arenaria (Hellou et al., 2003; Gauthier-Clerc et al., 2002; Gagné et al., 2003). Indeed, Vtg-like proteins are partially controlled by estradiol-17 $\beta$ and are readily induced by exposure to estrogens found in municipal wastewaters. Conversely, Vtg levels are significantly reduced at sites contaminated by tin compounds, including tributyltin. Energy status was determined by tracking energy expenditures and reserves, as indicated by temperature-dependent mitochondrial transport activity and gonad lipid contents (Gagné et al., 2007b; Smolders et al., 2004; De Coen and Janssen, 2003). Thermal stress was shown to increase oxidative stress due to the release of reactive oxygen species during cellular respiration (Abele et al., 2002; Heise et al., 2003). Mitochondria represent the major source of reactive oxygen species during electron transfer events to support oxidative phosphorylation and the formation of the proton gradient for ATP formation. The release of these reactive oxygen species was shown to be directly associated with the formation of the proton gradient, where uncoupling leads 
to proton release in the inner mitochondrial membrane. The early biochemical effects and defense mechanisms were determined by metallothioneins (MT) for heavy metal exposure and metabolism (Viarengo et al., 1997), xanthine oxidoreductase (XOR) and glutathione S-transferase (GST) activity for oxygen radical scavenging and conjugation of hydrophobic hydrocarbons (Gowland et al., 2002) respectively. XOR activity is the rate-limiting enzyme involved in the catabolism of purines and analogues such as caffeine and the drug theophyline. The enzyme is also implicated in the scavenging process of reactive oxygen species and in the process of adaptation to euryoxic and stenoxic conditions (Cancio and Cajaraville, 1999). Lastly, tissue damage was determined by measuring lipid peroxidation and DNA damage (Aldridge, 1997; Doyotte et al., 1997).

To further examine the cumulative effects of global changes in feral bivalve populations, biomarker research into the early biological effects of pollution requires that the scale of biomarker studies be expanded. However, most biomarker studies are undertaken relatively locally, often within the same country and even the same water bodies. The purpose of this study was to examine the global impacts of pollution on blue mussel populations in the Northern Hemisphere, spanning a distance of some $11000 \mathrm{~km}$ from the North American West Coast to the western coast of Europe. An attempt was made to relate pollution-mediated stress with physiological health status in the blue mussel Mytilus edulis.

\section{Methods}

\section{Sampling sites and mussel handling}


Blue mussels (Mytilus edulis) were collected from four regions, starting on the West Coast of Canada, near the city of Vancouver, British Columbia, heading east to the St. Lawrence estuary, near the town of Tadoussac, Quebec, thence to Halifax Harbour on the Atlantic East Coast, and ending in the Seine estuary on the western coast of Europe (Figure 1). The selected site sites were chosen based on their contamination profile in heavy metals (organotins) and/or aromatic hydrocarbons in surface water and sediments from Vancouver (Bolton et al., 2004), St-Lawrence estuary (Gagné et al., 2003), Halifax harbour (Hellou et al., 2002) and the Seine estuary (Cailleaud et al., 2007). One reference (less-impacted) site and two sites influenced by intense anthropogenic activities from marinas, commercial boath traffic and in the vicinity of urban areas were selected in each region. One of the two Vancouver sites (Van) was located on the north shore of the city, the other, downstream of the Simon Fraser River near Stanley Park (Stan), at the mouth of the Pacific Ocean; the reference site was located upstream in the town of Hopkins Landing. Sites in the St. Lawrence estuary include one at the harbour of Tadoussac (Tad) and another in the harbour of the town of Baie Sainte-Catherine (Bsc), subject to intensive commercial whale-watching boating traffic; the reference site was located at Baie-du-Moulin à Baude. In Halifax Harbour, one site was directly downstream of an untreated sewage effluent outfall $(\mathrm{E})$, while the other site $(\mathrm{M})$ was located in the Northwest Arm, a narrow, shallower area of the harbour with restricted water circulation; the reference site was at the extreme southern end of the harbour terminal. . Finally, in the Seine estuary, one site was located downstream of the harbour of the city of du Havre (Har) and the other site was located near Honfleur (Hon) in the South of the estuary. The reference site was located out of the estuary in the North (Yport) near the mouth of the 
Atlantic Ocean.At each site, 20 mussels with a shell length greater than $3 \mathrm{~cm}$ were collected at low tide during the first two weeks of June 2005. The mussels were immediately placed in polyethylene bags and stored in coolers (kept at $1-4^{\circ} \mathrm{C}$ ) for transport to the laboratory for the biochemical analyses. Mussels were then frozen on dry ice and shipped to the aquatic toxicology laboratory of Environment Canada in Montréal, Quebec, Canada, and stored at $-85^{\circ} \mathrm{C}$ until analysis.

\section{Tissue processing and morphometrics}

Mussels of similar sizes (4-6 cm shell length) from each region were thawed on ice. Each animal was measured (shell length in $\mathrm{mm}$ ) and weighed ( $\mathrm{g}$ wet weight of mussel, soft tissues and shells) to determine its condition factor (g mussel weight/mm shell length) and soft tissue weight ratio (g tissue weight/g mussel weight). Gills, digestive gland and gonadal tissues were dissected on ice and weighed to determine organ weight ratio (e.g. g gonad wet weight/g soft tissue wet weight). Sex was determined by taking gonadal smears on microscope glass slides (Gagné et al., 2003). Tissues were homogenized with a Teflon pestle tissue grinder in ice-cold $25 \mathrm{mM}$ Hepes-NaOH, pH 7.4, containing $130 \mathrm{mM}$ $\mathrm{NaCl}, 0.1 \mathrm{mM}$ EDTA and 0.1 dithiothreitol at a 1:5 weight/volume proportion. Aliquots of the homogenate and subsequent supernatants (see below) were taken for total protein determinations using serum bovine albumin for calibration (Bradford, 1976). A portion of the homogenate was set aside for DNA strand breaks, total lipids (gonad) and lipid peroxidation (LPO). The remaining homogenate was centrifuged at $3000 \times \mathrm{g}$ for $15 \mathrm{~min}$ at $2{ }^{\circ} \mathrm{C}$ to yield the mitochondria-enriched fraction for mitochondrial electron transport activity determinations. The remaining supernatant was centrifuged at $15000 \mathrm{x} \mathrm{g}$ for 20 min at $2^{\circ} \mathrm{C}$ for the remaining biomarkers (GST, MT, Vtg-like proteins, cytochrome 
P4503A and XOR activities). All biomarkers were normalized with total proteins in the corresponding supernatant fractions.

\section{Reproductive function}

Gametogenic activity was characterized by measuring the gonado-somatic index (weight of gonad/soft tissue weight; GSI), relative levels of vitellogenin-like proteins (Vtg) and gonad maturation index. Both sex and gonad maturation index were determined by examining gonadal smears at $400 \mathrm{X}$ enlargement. The maturation stages were ranked as follows: 1 for undifferentiated gonad; 2 development stage (early vitellogenesis) and fully developed gonad; and 3 for late gamete maturation and spawning. Maturation data was expressed as the mean value of the ranked stages. The organic alkali-labile phosphate (ALP) method using the acetone-fractionation procedure developed by Gagné et al. (2003) determined relative levels of Vtg-like proteins. A sub-sample of acetonefractionated proteins was analyzed on SDS-PAGE for cross-validation with the appearence of female-specific, high-molecular-weight proteins characteristic of Vtg. The Vtg data were expressed as $\mu \mathrm{g}$ of alkali-labile phosphates/mg proteins in supernatant.

\section{Biomarkers of defense and tissue damage}

Biomarkers of defense (MT, GST, XOR and cytochrome P4503A activtiy) and of tissue damage (LPO and DNA strand breaks) were determined in sampled blue mussels. Metallothioneins (MT) were determined in the gills and digestive glands of mussels. Relative levels of MT proteins were determined by the thiol microassay methodology (Viarengo et al., 1997). The solvent fractionation procedure was applied to the $15000 \mathrm{x} g$ 
supernatant and standards of reduced glutathione (GSH) were used for calibration. The data were expressed as $\mu$ moles of GSH equivalents/mg proteins. Glutathione Stransferase (GST) was determined by the spectrophotometric method of Boryslawskyj et al. (1988) using 2,4-dichloronitrobenzene (DCNB) as the substrate. The reaction assay contained $0.1 \mathrm{mM}$ of reduced GSH and 2,4-DCNB in the assay buffer (130 mM NaCl, 10 $\mathrm{mM}$ Hepes-NaOH, $\mathrm{pH}$ 7.4). The reaction was allowed to proceed for up to $30 \mathrm{~min}$ and absorbance readings were measured in a transparent 96 -well microplate at $350 \mathrm{~nm}$ (Powerwave Microplate Reader, USA). Data were expressed as the increase in absorbance at $350 \mathrm{~nm} / \mathrm{min} / \mathrm{mg}$ proteins. Cytochrome P4503A-like activtity was determined according to the dealkylation enzymatic assay with dibenzylfluorescein substrate (Gagné et al., 2007a; Quinn et al., 2004). The activity of xanthine oxidoreductase (XOR) was determined according to the dichlorofluorescein oxidation method in the presence of hypoxanthine (Zhu et al., 1994). The reaction mixture contained $1 \mathrm{mM}$ hypoxanthine, $2 \mu \mathrm{M}$ dichlorofluorescein in the assay buffer $(125 \mathrm{mM}$ $\mathrm{NaCl}, 10 \mathrm{mM}$ Hepes- $\mathrm{NaOH}$ ) in the presence of $50 \mu \mathrm{L}$ of the $\mathrm{S} 15$ supernatant of gonad homogenate. The reaction mixture was allowed to proceed at $30^{\circ} \mathrm{C}$ for $0,10,20$ and 30 min. The production of fluorescein was monitored at $485 \mathrm{~nm}$ excitation and $530 \mathrm{~nm}$ emission (Chameleon-II, Bioscan, USA).

Genomic and mitochondrial DNA damage were evaluated in gills and digestive glands by the alkaline DNA precipitation assay (Olive, 1988) with fluorescence determination of single and double-stranded DNA (Bester et al., 1994). Standards of salmon sperm DNA 
were used for calibration. The extent of lipid peroxidation (LPO) was determined by the thiobarbituric acid method (Wills, 1987). Blanks and standards of tetramethoxypropane were prepared in the presence of the homogenization buffer. Fluorescence was measured at $520 \mathrm{~nm}$ for excitation and $590 \mathrm{~nm}$ for emission using a fluorescence microplate reader (Chameleon-II, Bioscan, USA). Because the reagent could react with other aldehydes, results were expressed as $\mu \mathrm{g}$ of thiobarbituric acid reactants (TBARS)/mg of homogenate protein.

\section{Energy allocation}

Energy reserves were estimated by measuring total lipid levels in gonad. Lipid content in gonadal homogenates was determined according to the spectrophometric assay using phosphovanillin (Frings et al., 1972). Calibration was achieved with the neutral detergent Triton X-100 as the standard. The data were expressed as $\mu \mathrm{g}$ lipid equivalents/mg protein. Energy expenditure was determined by tracking mitochondrial respiratory activity in isolated mitochondria based on the reduction of p-iodonitrotetrazolium dye method (Smolders et al., 2004; King and Packard, 1975). Briefly, the mitochondrial fraction (50 to $100 \mu \mathrm{g} / \mathrm{mL}$ total proteins) was incubated in $0.1 \mathrm{M}$ Tris- $\mathrm{HCl}, \mathrm{pH} 8.5$, containing $0.1 \mathrm{mM} \mathrm{MgSO}$, $0.1 \%$ Triton X-100 and 5\% polyvinylpyrrolidone for 1 min before adding $1 \mathrm{mM}$ NADH and $0.2 \mathrm{mM}$ NAPDH. The reaction was immediately started by adding $100 \mu \mathrm{L}$ p-iodonitrotetrazolium at $5 \mathrm{mM}$, then allowed to proceed at $4^{\circ} \mathrm{C}, 10^{\circ} \mathrm{C}$ and $20^{\circ} \mathrm{C}$ for $30 \mathrm{~min}$ and absorbance readings taken at $520 \mathrm{~nm}$. The data were expressed as loss of dye absorbance $/ 30 \mathrm{~min} / \mathrm{mg}$ mitochondrial protein content. $\mathrm{MET}_{\mathrm{T}}$ activity was 
determined by the difference in MET at $20^{\circ} \mathrm{C}$ and $4^{\circ} \mathrm{C}$ divided by temperature change $\left(20-4^{\circ} \mathrm{C}=16^{\circ} \mathrm{C}\right)$ and total protein content: $\operatorname{MET}\left(20^{\circ} \mathrm{C}\right)-\operatorname{MET}\left(4^{\circ} \mathrm{C}\right) /\left(16^{*} \mathrm{mg}\right.$ proteins $)$.

\section{Data analysis}

Twelve mussels $(n=12)$ from each site were analyzed for biomarker measurements. Data distribution was analyzed using Bartlett's test for homogeneity of variances. When the data proved to be homogeneous, a two-way factorial analysis of variance with site and gender as the main factors was performed; critical differences between groups were appraised using the Fisher least-square difference test. In the case of nonhomogeneous data distributions, data were $\log _{10}$-transformed before performing a two-way factorial ANOVA or analyzed by Kruskal-Wallis rank ANOVA (followed by a Mann-Whitney U test for between site comparisons) for one-way analysis. Correlation analyses between biomarkers were determined using the Pearson-moment correlation and factorial analysis (principal components method). Site classification according to biomarker response was determined by discriminant analysis. All statistical tests were performed using the Statistica software package (version 7.1). Significance was set at $\mathrm{p}<0.05$.

Biomarker data from the spatial survey were also indexed using the integrated biomarker response (IBR) method (Beliaeff and Burgeot, 2002). This procedure enables the visualization of response patterns of a multivariable group of data using the integrated response and star plots. The IBR was calculated using a suite of biomarkers of physiological integrity and toxic stress. The biomarkers of physiological integrity were GSI, gonad lipids, MET at $25^{\circ} \mathrm{C}$ and Vtg-like proteins; the biomarkers of toxic stress 
were GST in digestive gland, MT and LPO in both gill and digestive gland, XOR in gonad, DNA damage in gill and digestive gland, and cytochrome P4503A activity.

\section{Results}

\section{Biomarker variation at the reference site from each regions}

Each study area included a reference or less-polluted site to permit comparison of responses within the various sectors (Table 1). The biomarker responses from the corresponding reference sites in each sector are supposedly the result of geographical habitat characteristics where the contribution of pollution-mediated effects should be minimal. An understanding of the natural range of physiological responses at a global scale would enable the scientific community to study changes occurring at much larger scales, including climate change or overfishing, in the context of the cumulative effects of various stressors. Across the 19 biomarkers examined, the distribution of biomarker responses deviated from normality in 16 cases $(84 \%)$, indicating that less-impacted sites could still differ markedly on a global scale (Table 2). Gonadal lipids, LPO in digestive glands and XOR activity were the only parameters that were normally distributed. In general, the difference between the mean and median biomarker responses differed 1.2fold from each other, with a minimum of 0.9 and maximum 2-fold difference indicating that the mean value was relatively close to the centre of gravity value (median) of the data distribution, which deviated from normality most of the time. The dispersion index (i.e. difference between maximum and minimum values normalized with mean value) varied from 0.8 to 3 for all biomarkers, with the exception of Vtg-like proteins, which had an index of 6. Based on the data spreading index (i.e. maximum value/minimum 
value), the biomarkers that varied least (i.e. spreading index $<10$ ) from the mean were gonad maturation, condition factor, soft tissue weight ratio, GSI, lipid stores in gonad, GST, MT in digestive gland, LPO in gills and digestive gland, and DNA strand breaks in gills and digestive gland. The biomarkers that varied the most were MET at $25^{\circ} \mathrm{C}, 6^{\circ} \mathrm{C}$ and $\mathrm{MET}_{\mathrm{T}}, \mathrm{MT}$ in gills, XOR, Vtg-like proteins and cytochrome P450 3A-like activity. These observations are consistent with the fact that these sites were subject to low-impact pollution, with correspondingly low variability in biomarkers of tissue damage such as LPO, DNA damage, MT and GST. In general, the mean discriminant factor value was 3.5, close to the number of regions (i.e. 4) studied here, indicating that these reference sites differed from each other. In keeping with this finding, the mean value of each biomarker will be shown with site-specific biomarker data in an attempt to account for the dispersed nature of each regional reference site.

\section{Biomarker responses in mussels from polluted sites}

We studied the morphological characteristics of mussels collected from four areas spanning the Pacific West Coast of Canada to the mouth of the Seine estuary on the northwest coast of Europe (Figure 2). The mean values of each biomarker were also examined in relation to the whole mean values of all reference sites in an attempt to determine the "natural" range of responses at a global scale. Condition factor (CF) differed only by site and not by gender (2-way ANOVA $p<0.05$ for site and $p>0.05$ for gender). In the Vancouver area, CF dropped 1.6-fold at the polluted sites (Stan and Van). In the St. Lawrence estuary region, CF also fell 1.6-fold at one of the polluted sites (Tad). In Halifax Harbour, the CF rose 1.3-fold at the site near the untreated effluent outfall. In 
the Seine estuary, the condition factor increased 1.3-fold at the polluted Hon site. Mussels from the reference sites in Vancouver and Halifax Harbour differed markedly from the global mean value of the reference sites; mussels from Halifax Harbour were significantly lower than the global reference value. The soft tissue weight ratio was also examined in blue mussels collected across the regions. A two-way ANOVA revealed that site and the interaction of site and gender were significant. Females from the reference site in the St. Lawrence estuary were generally heavier. No significant differences between males and females were observed at the other sites. Soft tissue content was significantly lower (1.6-fold) in the St. Lawrence region. Soft tissue content was significantly increased 1.5-fold in Halifax Harbour, while no significant changes were observed in the Vancouver region. In the Seine estuary, the ratio was significantly increased 1.12-fold at the Hon site. With respect to the mean value of the reference sites, the soft tissue content in mussels from Halifax Harbour was somewhat lower (by 1.2fold), but significantly higher at the reference site in the St. Lawrence estuary.

Gametogenesis was studied by measuring changes in GSI, gonadal maturation index and Vtg-like proteins (Figure 3). A two-way ANOVA revealed that site and sex differed significantly, with the male gonadal weight index being significantly higher than that of females. GSI was fairly constant across the regions, falling 1.4-fold at the Stan site in the Vancouver region and increasing 1.5-fold at the Tad site in the St. Lawrence estuary. The reference site in the Seine estuary was somewhat lower than the combined mean value of all reference sites. The gonadal maturation index differed significantly by site and gender, with a significant site-gender interaction. Gonad maturation was significantly higher in 
females than in males, females from the Vancouver region being more mature than those in the other study regions. Mussels at the Tad site in the St. Lawrence had significantly lower maturation. No significant change in the gonad maturation index at the reference sites. Levels of Vtg-like proteins were also examined and revealed significant changes across all sites. A two-way ANOVA showed that levels of Vtg-like proteins in mussels from the site near the raw sewage outfall (200 m distance) were significantly higher than at the corresponding reference site. The elevation of Vtg-like proteins was significantly stronger in males than in females at the outfall (over 9-fold increase in males and 5-fold increase in females), suggesting the input of estrogenic compounds. In the Seine estuary, a decrease in Vtg-like proteins was observed at the harbour site Har with a 3-fold decrease. Vtg-like proteins in mussels at the reference sites in the Seine estuary and in the Vancouver region increased 4-fold and decreased 2-fold, respectively, compared to the mean value of all reference sites. A correlation analysis revealed that GSI was negatively correlated, albeit marginally, with soft tissue weight ratio $(r=-0.17 ; p=0.08)$. The gonad maturation index was significantly correlated with GSI $(r=-0.17)$ and Vtg-like proteins $(r=-0.27)$. All further correlations mentioned in the text are presented in Table 3.

Changes in energy status (MET and total lipids) and temperature-dependence in energy expenditures were examined in gonad homogenates (Figure 4). MET at $25^{\circ} \mathrm{C}$ was significantly affected by site, but gender was not significant. In Vancouver, MET at $25^{\circ} \mathrm{C}$ was increased 2.5-fold at the Stan site. In the St. Lawrence estuary, activity was 2.6-fold higher at the Tad site only. Activity at $25^{\circ} \mathrm{C}$ remained fairly constant for the Halifax Harbour and the Seine estuary sites, although they rose (1.8-fold) and fell (1.8-fold) 
significantly at the reference sites in the Seine estuary and Vancouver regions, respectively. MET activity at $6^{\circ} \mathrm{C}$ was also significantly influenced by site but gender was not significant. In Vancouver, MET at a cold temperature was significantly reduced by about 1.75-fold for both the Stan and Van sites. In the St. Lawrence estuary, MET activity at $6^{\circ} \mathrm{C}$ was significantly induced 2.2-fold at the Tad site. The reference site in the Seine estuary was significantly higher than the mean value of all the reference sites. $\mathrm{MET}_{\mathrm{T}}$ was significantly affected by site but gender was not significant. $\mathrm{MET}_{\mathrm{T}}$ was significantly increased by 3.6-fold at the Tad site in the St. Lawrence estuary and 1.8-fold at the Van site in the Vancouver area. Gonadal lipid levels changed significantly by site alone, with gender having no significant effect. Lipid levels were significantly higher (1.4-fold) at the Stan site (Vancouver region), and the Tad site (St. Lawrence estuary), and 1.5-fold at the impacted sites in the Seine estuary. A correlation analysis revealed that MET at $25^{\circ} \mathrm{C}$ was significantly correlated with gonad maturation $(\mathrm{r}=-0.3)$, soft tissue weight ratio $(r=-0.22)$, GSI $(r=-0.18)$, MET at $6^{\circ} \mathrm{C}(r=0.73)$, and with Vtg-like proteins $(r=0.25)$. MET at $6^{\circ} \mathrm{C}$ was significantly correlated with gonad maturation $(r=-$ $0.2)$, soft tissue weight ratio $(\mathrm{r}=-0.29)$, GSI $(\mathrm{r}=-0.23)$, and Vtg-like proteins $(\mathrm{r}=0.25)$. $\mathrm{MET}_{\mathrm{T}}$ was significantly correlated with Vtg-like proteins $(\mathrm{r}=-0.24)$. Gonad lipids were significantly correlated with Vtg-like proteins $(r=-0.21)$.

Biomarkers of defence mechanisms were examined in mussels by tracking changes in GST activity, XOR, MT and cytochrome P4503A-like activity (Figure 5). GST activity in the digestive gland varied significantly across all sites, with gender having no significant effects. GST activity was readily induced 2-fold at the Vancouver Stan site and 
significantly reduced 1.3-fold at site E and 1.9-fold at site Har and 1.7-fold at Halifax Harbour and the Seine estuary harbour site, respectively. GST activity at the leastimpacted (reference) sites grew 1.3-fold, 1.8-fold and fell 2.2-fold, respectively, in the Halifax Harbor, Seine estuary and Vancouver regions. A correlation analysis revealed that GST was significantly correlated with condition factor $(r=-0.3)$, GSI $(r=-0.21)$, MET at $25^{\circ} \mathrm{C}(\mathrm{r}=0.2), \mathrm{MET}_{\mathrm{T}}(\mathrm{r}=-0.3)$ and Vtg-like proteins $(\mathrm{r}=0.32)$. The electronscavenging activity of XOR was also examined and found to have changed significantly only by site, with no gender-related effects. XOR activity was significantly increased by 3.6-fold at the Stan site in Vancouver, by 3.3-fold at Tad and by 2.6-fold at Bsc, both sites in the St. Lawrence estuary. XOR activity was significantly reduced by 3.5 -fold at sites $\mathrm{M}$ and $\mathrm{E}$, both in Halifax Harbour, while no significant changes were observed in mussels from the Seine estuary. In specimens from the reference sites in Vancouver and the Halifax Harbour region, respectively, XOR activity fell 1.8-fold and rose 2.1-fold. A correlation analysis revealed that the following biomarkers were significantly correlated: condition factor and soft tissue index $(r=-0.4$ and $r=-0.26)$, lipids $(r=0.2)$ and MET at $25^{\circ} \mathrm{C}(\mathrm{r}=0.25), \mathrm{MET}_{\mathrm{T}}(\mathrm{r}=0.28)$ and GST $(\mathrm{r}=0.45)$. Levels of MT in gills and digestive gland were also examined in mussels. Gill MT levels changed significantly based on site, with no gender-related effects. Gill MT rose significantly (two-fold) at the Bsc site but was significantly reduced by 2.8 -fold at site $\mathrm{E}$ and by 1.3 -fold at the Bri site in Halifax Harbour. MT levels in gills at the references sites revealed that the Vancouver reference site was significantly lower (1.8-fold) than the overall mean. Gill MT was significantly correlated with gonadal lipids $(r=0.24)$, GST $(r=0.23)$ and XOR $(r=0.37)$. MT levels in digestive gland changed significantly across the sites, with a significant influence by 
gender $(p=0.05)$ but no significant interaction between site and gender. Males tended to have more MT than females. Digestive gland MT was significantly (two-fold) higher at the Stan site and 1.5-fold higher at the Tad site. MT levels were reduced three-fold at site M and two-fold at site E, both in Halifax Harbour, with no significant change for the Seine estuary sites. Digestive gland MT was significantly correlated with the soft tissue weight ratio $(\mathrm{r}=-0.33)$, gonadal lipids $(\mathrm{r}=0.33)$, MET at $25^{\circ} \mathrm{C}(\mathrm{r}=0.37), \mathrm{MET}_{\mathrm{T}}(\mathrm{r}=$ $0.38)$ and XOR activity $(\mathrm{r}=0.24)$. The activity of cytochrome $3 \mathrm{~A}$ activity, implicated in the biotransformation of many pharmaceuticals, was also examined and found to have changed significantly by study site with no effects by gender. Cytochrome P450 3A activity increased significantly 2.3 -fold at the Stan site in Vancouver and by 4-fold at the Tad site in the St. Lawrence estuary. At the Hon site in the Seine estuary, CYP 3A activity rose 1.4-fold; its activity decreased 3.9-fold at site $\mathrm{M}$ in Halifax Harbour. Relative to the global mean value of the reference sites, activity levels at the Vancouver reference site were 1.4-fold lower, but 1.8-fold higher in the Seine estuary. A correlation analysis revealed that the following biomarkers were markedly correlated: gonad maturation index $(r=-0.21)$, soft tissue weight ratio $(r=-0.26)$, MET at $25^{\circ} \mathrm{C}(\mathrm{r}=0.54)$ and at $6^{\circ} \mathrm{C}(\mathrm{r}=0.46)$, GST $(\mathrm{r}=0.37)$, MT in gills $(\mathrm{r}=0.23)$ and digestive gland $(\mathrm{r}=$ 0.28), XOR activity $(\mathrm{r}=0.61)$, gill LPO $(\mathrm{r}=0.44)$ and Vtg-like proteins $(\mathrm{r}=0.35)$.

Tissue damage was examined by following lipid peroxidation and DNA strand breaks in gills and digestive gland (Figure 6). LPO in gills was influenced by site with no genderrelated effect. Gill LPO was significantly decreased by 1.6 -fold at site Tad in the St. Lawrence estuary, by 1.5-fold at the Har site in Halifax Harbour and by 1.7-fold at the 
Hon site in the Seine estuary. The reference site in the Seine estuary was 2.3-fold higher than the global mean value of all the reference sites. A correlation analysis revealed that the following parameters were significant: soft tissue weight ratio $(r=-0.2)$, GSI $(r=-$ 0.26), gonadal lipids $(\mathrm{r}=-0.37)$, MET at $25^{\circ} \mathrm{C}(\mathrm{r}=0.39)$ and at $6^{\circ} \mathrm{C}(\mathrm{r}=0.53)$, Vtg-like proteins $(r=0.47)$ and cytochrome P4503A activiy $(r=0.4)$. LPO in digestive gland changed significantly from site to site, but gender had no influence. LPO levels were increased 1.6-fold at Tad in the St. Lawrence and significantly reduced in Halifax Harbour (2.35-fold at site $\mathrm{M}$ and 1.7-fold at site E). With respect to the global mean value of the reference sites, LPO in digestive gland was reduced 1.5 -fold in the St. Lawrence estuary and increased 1.4-fold in Halifax Harbour. A correlation analysis revealed significant relationships with soft tissue weight index $(r=-0.29), \mathrm{MET}_{\mathrm{T}}(\mathrm{r}=0.31)$ and GST $(r=-0.23)$, MT in digestive gland $(r=0.43)$, XOR $(r=0.23)$ and Vtg-like proteins $(\mathrm{r}=-0.22)$. DNA strand breaks in gill tissues changed significantly across the study sites, with no effect for gender. Gill DNA breaks were significantly lower at both Vancouver sites (1.3-fold at Stan and 1.5-fold at Van), and dropped 1.8-fold at the Har site in Halifax Harbour. DNA breaks in gills were significantly increased 1.7-fold at the Hon site in the Seine estuary. The Vancouver reference site contained more DNA strand breaks in gills relative to the overall value of the reference sites. A correlation analysis revealed that DNA strand breaks in gills were significantly correlated with condition factor $(\mathrm{r}=0.28)$, GST $(r=-0.36)$ and gill MT $(r=-0.35)$. DNA strand break levels in digestive glands varied significantly by site and with gender. Males tended to have higher DNA strand breaks than females. DNA strand breaks in digestive glands dropped by 1.7 -fold at the Stan site in Vancouver, by 6.7-fold at Har in Halifax Harbour but rose 6.4-fold at the Hon 
site in the Seine estuary. Moreover, the reference sites in the St. Lawrence and Seine estuary declined 1.9- and 2-fold, respectively, relative to the overall value of the reference sites. A correlation analysis revealed that the following markers were correlated: GSI $(r=0.28)$, gonadal lipids $(r=-0.33)$, GST $(r=-0.36)$, XOR $(r=-0.24)$ and DNA strand breaks in gills $(r=0.46)$.

\section{Multivariate analyses of biomarker data}

Multivariate analyses were determined using the integrative biomarker response discriminant, principal component analyses and the IBR index, and (figures 7 and 8). A discriminant analysis revealed that sites were correctly classified to their specific regions with the following success rate: $87 \%$ for the St. Lawrence region, $90 \%$ for Halifax Harbour, 93\% for the Vancouver region, and 100\% for the Seine estuary. Mussels from the Seine estuary were the most easily discriminated compared to the other three regions. The Vancouver, St. Lawrence and Halifax regions were mostly distinguished by the Yaxis (root 2 function), where biomarker condition factor, GST and MT in digestive glands had the highest factorial weights. The Seine estuary was mostly discriminated by the Xaxis (root 1 function), where the biomarkers MET at $6^{\circ} \mathrm{C}$, LPO in gills and MET at $25^{\circ} \mathrm{C}$ had the highest factorial weights. A factorial analysis of all mussels regardless of region revealed that only $30 \%$ of the variance could be explained. The biomarkers with factorial weights $>60 \%$ were MET at $25^{\circ} \mathrm{C}$, cytochrome P450 3A-like activity, Vtg-like proteins and gill LPO. The IBR index showed that the physiological biomarkers (MET at $25^{\circ} \mathrm{C}$, gonadal lipids, GSI and Vtg-like proteins) were relatively constant across all four regions, but biomarkers of stress (all other biomarkers without condition factor) were more 
variable. For the physiological biomarkers, surface area was more pronounced in gonadal lipids in mussels of the Vancouver area, while both GSI and gonadal lipids were more pronounced in mussels in the St. Lawrence estuary. The surface area appeared symmetric (i.e. equal distribution of biomarker responses) with mussels in Halifax Harbour and the Seine estuary, with a stronger tendency towards Vtg-like proteins for the latter. For the stress biomarkers, the surface area increased significantly (Kruskal Wallis ANOVA and rank sum test $\mathrm{p}<0.001)$ in mussels from the Seine estuary. In the Seine estuary, cytochrome P4503A activity, LPO in gills and DNA damage in gills and GST were the major biomarker responses in blue mussels.

\section{Discussion}

The distribution of biomarkers from the low-impacted sites varied across all the study areas. The distribution of the biomarker data generally departed from normality, with discriminant factors being close to the number of regions (i.e. ranging from 2.8 to 5), thus suggesting that geographical area has a significant effect on "baseline" biomarker values. However, a small number of biomarkers were normally distributed, indicating a homogeneous distribution of the data rather than a tendency for an attraction around a central value: lipids in gonad (energy reserves) and LPO in digestive gland and the oxygen radical scavenging activity of XOR. This observation excludes the existence of an overall "reference" or central value to permit comparisons with a global measurement at the scales implicated (11000 km in the Northern Hemisphere) in the present study. The inclusion of a reference site for each region should, of course, be maintained in ecotoxicological studies regardless of the scale of the survey. The biomarkers with the 
biggest ranges of response were Vtg-like proteins, DNA damage in digestive gland, cytochrome P4503A activity and MET at $25^{\circ} \mathrm{C}$ and at $6^{\circ} \mathrm{C}$ and $\mathrm{MET}_{\mathrm{T}}$, indicating that energetics, oxidative metabolism, genotoxicity and vitellogenesis are the main drivers of bivalve susceptibility to pollution and other global processes like climate change. Shell/soft-tissue growth and tissue composition responded to eutrophic-driven changes such as oxygen levels and nutrients (Carmichael et al., 2004). Nitrogen enrichment of near-bottom seston and surface sediment increases microalgal concentrations and reduces carbon-to-nitrogen ratios, thus increasing the quantity and quality of available foods, but at the expense of habitat quality by reducing oxygen content. Shell growth in juvenile and native clams increases with food supply, driven by $\mathrm{N}$ enrichment. Low salinity also limits growth generally and low oxygen may reduce survival. In this study, mussel condition factor at the reference sites was higher in Vancouver and lower in Halifax Harbour, suggesting differential eutrophication. This finding was further supported by the negative correlation between conditon factor and XOR activity with an absence of significant trends in oxidative stress (LPO). Hence, high tissue and shell growth were associated with low oxygen radical scavenging activity, corroborating a eutrophic effect in blue mussels at some sites. It seems that in a eutrophic-driven system (Vancouver, the St. Lawrence and to a lesser extent Seine estuary, pollution has a negative effect on shell and tissue growth and a positive effect on XOR activity. Conversely, in Halifax Harbour, pollution appears to have a positive effect on condition factor and a negative effect on XOR activity (low oxygen uptake), thus reinforcing a nutrient-depleted or eutrophic environment. In other words, in less eutrophic environments with low nutrient intake, pollution simulates a eutrophic effect; the opposite was shown in environments rich in 
nutrients. In addition to temperature, the variable of nutrient input (eutrophication) seems to contribute to mussel health status such that energy budget and gametogenic activity are physiologically linked. Although MT levels were fairly stable in a natural population of Ruditapes decussatus, metals and MT concentrations increased with condition factor in gills and digestive glands at the expense of the remaining tissues (Bebianno and Serafim, 2003). We observed no such correlations with Mytilus edulis mussels in the present survey. In another study, biomarkers (aldehyde dehydrogenase, catalase, neutral red retention and condition index) were distributed according to temperature and four seasonal groups, indicating that temperature, in addition to reproduction, has a profound effect on bivalve physiology (Nesto et al., 2004). These authors also suggested that both spatial and temporal surveys were required to distinguish physiological variations from natural and anthropogenic stress.

The gamete maturation index was remarkably constant across the regions (it had the lowest discrimination factor at 2.8), whereas only one site in the St. Lawrence estuary (Tad) was significantly lower. In general, levels of Vtg-like proteins were somewhat higher compared to the reference sites. An analysis of covariance was performed to circumscribe site-specific effects related to estrogens from "confounding" variables such as the gametogenic cycle, which may differ geographically according to the nutritional and thermal histories of the regions. The analysis revealed that cytochrome P4503A, gonad maturation, sites and GSI, in that order, were significant below the $\mathrm{p}<0.001$ level. Because vitellogenesis occurs at the beginning of gamete development, GSI would be less significant than the gonad maturation stage. The remaining and still highly 
significant site-specific effects after correction for gametes developmental variables support the hypothesis of exposure to environmental estrogens, with mussels living in proximity $(<200 \mathrm{~m})$ of raw sewage in Halifax Harbour having the strongest response. It is noteworthy that Vtg-like protein levels in mussels from polluted sites in the Seine estuary were not significantly induced relative to the area's least-polluted site. However, levels were all significantly induced with respect to the mean rank value $(\mathrm{p}<0.05$; MannWhitney $\mathrm{U}$ test for data distribution that deviates from normality) of Vtg-like protein values for all the reference sites combined, suggesting a more global response to the estrogens released by the Seine River, which drains the most populated areas of western Europe and is greatly contaminated (Cachot et al., 2006). It is noteworthy that the Seine estuary contained significant levels of pharmaceutical products (Budzinsky H., personal communication, ECOBIM 2007), where cytochrome P4503A represents a major drugmetabolizing enzyme. This enzyme complex also possesses $6 \beta$-testosterone hydroxylase activity which is implicated in the turnover of testosterone, thereby estradiol-17ß. However, an analysis of covariance of cytochrome P4503A activity with levels of Vtglike proteins and gonad maturation index revealed that although gamete activity was not significant, the residual site-specific effects remained so, suggesting the effects of this type of contamanition in blue mussels in the Seine estuary and other regions as well. The energy required to support vitellogenesis by endogenous or exogenous inputs of estrogenic contaminants represents another major expenditure for bivalves, thus contributing to the increase in energy demands (Smolders et al., 2004), as corroborated by the correlation between Vtg-like proteins and MET. Interestingly, temperaturedependent MET was negatively correlated with vitellogenesis but positively so with XOR 
activity, suggesting that temperature acclimation occurs at the expense of gametogenic activity in oxygen-rich environments.

Energy allocation of mussels was a marked physiological variable in the blue mussels from the four regions examined, as revealed by IBR, principal component and correlation analyses. Indeed, the IBR value revealed marked effects on GSI, MET at $25^{\circ} \mathrm{C}$ and lipid reserves in the gonad, where mitochondrial activity (i.e., energy expenses) showed the strongest correlations with cytochrome P4503A activity, MET at cold temperatures, oxidative stress and increased MT expressions. Exposure to pharmaceutical products and urban effluents were shown to increase MET activity in freshwater mussels (Gagné et al., 2006). The strong contribution of energy demand (MET at warm and cold temperatures) with various biomarkers in mussels under the cumulative effects of pollution, reproductive and nutritional stresses, implicate a common physiological pathway. This was supported by an analysis of covariance showing that MET was significantly related to (in decreasing order of significance) GSI and Vtg-like proteins and site-specific effects, where condition factor and gonadal lipids (nutritional input) were not significant. Energy allocation was shown to decline with increased MET and lower lipid reserves in zebra mussels exposed to pollutants (Smolders et al., 2004). The MET-to-lipid ratio generally rose across the polluted sites, with mussels from the Seine estuary responding most, indicating a negative energy budget. Moreover, an analysis of covariance showed that Vtg-like protein levels were the major contributor but that sites remained highly significant $(\mathrm{p}<0.001)$, suggesting that decreased Vtg-like proteins were directly related to decreased MET-to- lipid ratio. The decreased MET/gonadal lipid ratio was related to 
adaptation to ambient water temperatures (Gagné et al., 2007b). Mya arenaria clams adapted to warm temperatures had increased MET/lipid ratios at polluted sites, indicating that the cumulative effects of warmer temperatures and pollution contributes to lower energy budgets. In the present study, MET/lipid ratios were higher at polluted sites in all regions, with the strongest response observed in the Seine estuary and Vancouver regions. These results agree with the observation that these regions were warmer than the others. Moreover, $\mathrm{MET}_{\mathrm{T}}$ activiy was indeed elevated in the Vancouver region, but not at the Seine estuary sites, suggesting perhaps that the high mitochondrial activity at $25^{\circ} \mathrm{C}$ and $6^{\circ} \mathrm{C}$ observed in mussels from the Seine estuary occurs at the expense of temperature sensitivity. This may be another sign of adaptation to warmer temperatures, as observed with the MET/lipid ratio. Temperature was shown to enhance mitochondrial respiration and the production of reactive oxygen species in the eurythermal bivalve Mya arenaria (Abele et al., 2002). Higher temperatures $\left(20^{\circ} \mathrm{C}\right)$ favour mitochondrial uncoupling which in turn leads to the production of reactive oxygen species. This production could represent up to $4.3 \%$ of total oxygen consumption and also provides a physiological link with eutrophication and nutrient loadings. Indeed, the degree of oxygen regulation $\left(\mathrm{O}_{2}\right.$ uptake rate) increased in temperatures ranging from 5 to $15^{\circ} \mathrm{C}$, but declined with temperatures above this range in zebra mussels (Alexander and McMahon, 2004). The decreased metabolic rate in the upper temperature range permits conservation of organic energy stores during warming months. Thus, warmer habitat temperatures might increase metabolic rates (oxygen consumption and MET) to the extent that eutrophication could compromise this process when oxygen tension is lowered. Thermal history was also shown to influence the threshold induction temperature for heat shock proteins in 
intertidal blue mussels, suggesting that thermal and habitat quality both could influence susceptibility to environmental stressors such as pollution and global warming (Buckley et al., 2001). These investigators found that the threshold induction temperature of heatshock transcription factor 1 in $M$. trossulus was $23^{\circ} \mathrm{C}$ in Febuary and $28^{\circ} \mathrm{C}$ in August, indicating that these organisms have the ability to adjust their sensitivity to temperature. In another study, temperature increased the sensitivity of zebra mussel hemocytes to the model genotoxic compounds mephalan or sodium hypochlorite in vitro (Buschini et al., 2003). Indeed, in mussels acclimated to temperatures for $15 \mathrm{~h}$, DNA damage was greater at temperatures of up to $28^{\circ} \mathrm{C}$, but a minimum of $18^{\circ} \mathrm{C}$ was required after just $1 \mathrm{~h}$ of exposure of the above genotoxicants to hemocytes in vitro.

In addition to oxygen availability, nutrients and temperature, MET activity was also shown to respond to pollutants in invertebrates (De Coen and Janssen, 2003). This was corroborated in our study by the observation that MET at $25^{\circ} \mathrm{C}$ in gonad was higher in mussels collected at more polluted sites and significantly correlated with MT in digestive gland and oxidative stress biomarkers: XOR in gonad, GST, LPO in gills and cytochrome P4503A activity. The interaction of temperature-related effects in mitochondria with cadmium was observed in oysters (Cherkasov et al., 2007). Temperature-related stress $\left(30^{\circ} \mathrm{C}\right)$ increased the toxicity of cadmium, leading to oxidative stress and inactivation of aconitase in oyster mitochondria. Although cytochrome P4503A represents one of the major drug metabolizing enzymes for pharmaceutical products (Crespi et al, 1997), it is also responsible for $6 \beta$-testosterone metabolism in the turnover of androgens in fish (James et al., 2005) and immunopositive proteins towards cytochrome P 4503A were 
found in blue mussels (Peters et al., 1998). Its activity was significantly correlated with Vtg-like proteins in our study, suggesting a link with steroidal metabolism that occurs during vitellogenesis in bivalves (Gauthier-Clerc et al., 2006). An analysis of covariance revealed that Vtg-like proteins were strongly related, in decreasing order, to cytochrome P4503A activity, gonad maturation and site-specific effects, supporting the finding that its activity was strongly influenced by steroidal metabolism for the production of Vtg-like proteins. Site-specific effects remained significant, suggesting that pollution-mediated effects caused by the presence of polar (hydroxyl and amine) hydrocarbons such as pharmaceutical products are likely. It is noteworthy that cytochrome P3403A and 2C are the two major drug-metabolizing enzymes in vertebrates, their associated activity with the DBF substrate being induced in mussels by municipal effluents, a recognized source of pharmaceuticals for the aquatic environment (Gagné et al., 2007a). Interestingly, LPO in the digestive gland was more strongly related with MT in these same tissues than with MET at $25^{\circ} \mathrm{C}$, suggesting that oxidative damage was related to the MT response (ie., heavy metal mobilisation was related to the formation of oxygen radicals). Moreover, the activity of the conjugating enzyme GST was negatively correlated with DNA damage and LPO in the digestive gland and positively so with cytochrome P4503A, suggesting a detoxification pathway rather than bioactivation. These responses indicate that heavy metals appear to have contributed more to tissue damage than did organic compounds in the present study. Evaluating the impacts of pollution in the context of global processes such as climate change (warming) permitted to identify regions under pollution stress with increased sensitivity to temperature changes in the Northern hemisphere.

Acknowledgments. The biomarker analyses were performed by Sophie Trépanier and Chantale André of Environment Canada. The geographical maps were produced by 
François Boudreault, Environment Canada. The manuscript was edited by Patricia Potvin, Environment Canada. This work was supported by Environment Canada. The authors thank Michel Fournier, head of the CIRÉ network, of which they are members, which assembles research initiatives on aquatic ecotoxicology in Québec, Canada. Mussels were sampled by Prof. F. Le Boulenger, LEMA, Université du Havre.

\section{References}

Abele, D.; Heise, K.; Portner, H.O.; Puntarulo, S. Temperature-dependence of mitochondrial function and production of reactive oxygen species in the intertidal mud clam Mya arenaria. J Exp Biol. 205, 1831-1841; 2002

Aldridge, W.N. "Stages in the Induction of Toxicity." In: Mechanisms and Concepts in Toxicology. Taylor \& Francis Publishers, London, England, 249 pp; 1997

Alexander, J.E. Jr.; McMahon, R.F. Respiratory response to temperature and hypoxia in the zebra mussel Dreissena polymorpha. Comp Biochem Physiol. 137A, 425-434; 2004

Bebianno, M.J.; Serafim, M.A. Variation of metal and metallothionein concentrations in a natural population of Ruditapes decussatus. Arch Environ Contam Toxicol. 44, 53-66; 2003

Beliaeff, B.; Burgeot, T. Integrated biomarker response: A useful tool for ecological risk assessment. Environ Toxicol Chem. 21, 1316-1322; 2002

Bester, M.J.; Potgieter, H.C.; Vermaak, W.J.H. Cholate and $\mathrm{pH}$ reduce interference by SDS in the determination of DNA with Hoescht. Anal Biochem. 223, 299-305; 1994

Bolton, J.L.; Ster, C.M.; Boyd, D.T.; Burrows, D.G.; Talin. A.V.; Lishavskaya, T.S. Organic and trace metal contaminants in sediments and English sole tissues from Vancouver Harbour, Canada. Mar Environ Res. 57, 19-36; 2004

Boryslawskyj, M.; Garrood, A.C.; Pearson, J.T. Elevation of glutathione-S-transferase activity as a stress response to organochlorine compounds, in the freshwater mussel, Sphaerium corneum. Marine Environ Res. 24, 101-104; 1988

Buckley, B.A.; Owen, M.E.; Hofmann, G.E. Adjusting the thermostat: The threshold induction temperature for the heat-shock response in intertidal mussels (genus Mytilus) changes as a function of thermal history. J Exp Biol. 204, 3571-3579; 2001

Buschini, A.; Carboni, P.; Martino, A.; Poli, P.; Rossi, C. Effects of temperature on baseline and genotoxicant-induced DNA damage in haemocytes of Dreissena polymorpha. Mutat Res. 537: 81-92; 2003

Cachot, J.; Geffard O.; Auganeur S.; Lacroix S.; Le Menach K.; Peluhet L.; Couteau J.; Denier X.; Devier M.H.; Pottier D.; Budzinski H.. Evidence of 
genotoxicity related to high PAH content of sediments in the upper part of the Seine estuary (Normandy, France). Aquat Toxicol. 79, 257-267; 2006

Cailleaud, K.; Forget-Leray, J.; Souissi, S.; Hilde, D.; Lemenach, K.; Budzinski, H. Seasonal variations of hydrophobic organic contaminant concentrations in the watercolumn of the Seine Estuary and their transfer to a planktonic species Eurytemora affinis (Calanoida, copepoda). Part 1: PCBs and PAHs. Chemosphere In press; 2007

Cancio, I.; Cajaraville, M.P. Seasonal variation of xanthine oxidoreductase activity in the digestive gland cells of the mussel Mytilus galloprovincialis: A biochemical, histochemical and immunochemical study. Biol Cell. 91, 605-615; 1999

Carmichael, R.H.; Shriver, A.C.; Valiela, I. Changes in shell and soft tissue growth, tissue composition, and survival of quahogs, Mercenaria mercenaria, and softshell clams, Mya arenaria, in response to eutrophic-driven changes in food supply and habitat. J Exp Mar Biol Ecol. 313, 75-104; 2004

Cherkasov, A.A.; Overton, R.A. Jr.; Sokolov, E.P.; Sokolova, I.M. Temperaturedependent effects of cadmium and purine nucleotides on mitochondrial aconitase from a marine ectotherm, Crassostrea virginica: A role of temperature in oxidative stress and allosteric enzyme regulation. J Exp Biol. 210, 46-55; 2007

Crespi, C.L.; Miller, V.P.; Penman, B.W. Microtiter plate assays for inhibition of human, drug-metabolizing cytochromes P450. Anal Biochem. 248, 188-190; 1997

De Coen, W.; Janssen, C.R. The missing biomarker link: Relationships between effects on the cellular energy allocation biomarker of toxicant- stressed Daphnia magna and corresponding population characteristics. Environ Toxicol Chem. 22, 1632-1641; 2003

Doyotte, A.; Cossu, C.; Jacquin, M.C.; Babul, M.; Vasseur, P. Antioxidant enzymes, glutathione and lipid peroxidation as relevant biomarkers of experimental or field exposure, in the gills and the digestive gland of the freshwater bivalve Unio tumidus. Aquat Toxicol. 39, 93-110; 1997

Frings, C.S.; Fendley, T.W.; Dunn, R.T.; Queen, C.A. Improved determination of total serum lipids by the sulfo-phospho-vanillin reaction. Clin Chem. 18, 673-674; 1972

Gagné, F.; Blaise, C.; Pellerin, J.; Pelletier, E.; Douville, M.; Gauthier-Clerc, S.; Viglino, L. Sex alteration in soft-shell clams (Mya arenaria) in an intertidal zone of the St. Lawrence River (Québec, Canada). Comp Biochem Physiol. 134C, 189-198; 2003

Gagné, F.; Blaise, C.; André, C. Implication of site quality on mitochondrial electron transport activity and its interaction with temperature in feral Mya arenaria clams from the Saguenay Fjord. Environ Res. 103, 238-246; 2007a 
Gagné, F.; Blaise, C.; André, C.; Gagnon, C.; Salazar, M. Neuroendocrine disruption and health effects in Elliptio complanata mussels exposed to aeration lagoons for wastewater treatment. Chemosphere 143, 731-743; 2007b

Gagné, F.; Blaise, C.; André, C.; Salazar, M. Effects of pharmaceutical products and municipal wastewaters on temperature-dependent mitochondrial electron transport activity in Elliptio complanata mussels. Comp Biochem Physiol. 143, 388-393; 2006

Gauthier-Clerc, S.; Pellerin, J.; Blaise, C.; Gagné, F. Delayed gametogenesis of Mya arenaria in the Saguenay Fjord (Canada): A consequence of endocrine disruptors? Comp Biochem Physiol. 131C, 457-467; 2002

Gauthier-Clerc, S.; Pellerin, J.; Amiard, J.C. Estradiol-17ß and testosterone concentrations in male and female Mya arenaria (Mollusca: Bivalvia) during the reproductive cycle. Gen Comp Endocrinol. 145:133-139; 2006

Gowland, B.T.; McIntosh, A.D.; Davies, I.M.; Moffat, C.F.; Webster, L. Implications from a field study regarding the relationship between polycyclic aromatic hydrocarbons and glutathione S-transferase activity in mussels. Mar Environ Res. 54, 231-235; 2002

Heise, K.; Puntarulo, S.; Portner, H.O.; Abele, D. Production of reactive oxygen species by isolated mitochondria of the Antarctic bivalve Laternula elliptica under heat stress. Comp Biochem Physiol. 134A, 79-90; 2003

Hellou, J.; Yeats, P.; Gagné, F. Chemical contaminants and biological indicators of mussel health during gametogenesis. Environ Toxicol Chem. 22, 2080-2087; 2003

Hellou, J.; Steller, S.; Zitko, V.; Leonard, J.; King, T.; Milligan, T.G.; Yeats, P.; Distribution of PACs in surficial sediments and bioavailability to mussels, Mytilus edulis of Halifax Harbour. Mar Environ Res. 53, 357-379; 2002

James, M.O.; Zhen Lou, J.; Rowland-Faux, L.; Celander, M.C. Properties and regional expression of a CYP3A-like protein in channel catfish intestine. Aquat Toxicol. 72, 361$371 ; 2005$

King, F.; Packard, T.T. Respiration and the activity of the respiratory electron transport system in marine zooplankton. Limnol Oceanog. 20, 849-854; 1975

Nesto, N.; Bertoldo, M.; Nasci, C.; Da Ros, L. Spatial and temporal variation of biomarkers in mussels (Mytilus galloprovincialis) from the Lagoon of Venice, Italy. Mar Environ Res. 58, 287-291; 2004

Olive, P.L. DNA precipitation assay: A rapid and simple method for detecting DNA damage in mammalian cells. Environ Mol Mutagen. 11, 487-495; 1988 
Peters, L.D.; Nasci, C.; Livingstone, D.R. Variation in levels of cytochrome P4501A, 2B, 2E, 3A and 4A-immunopositive proteins in digestive gland of indigenous and transplanted mussel Mytilus galloprovincialis in Venice lagoons, Italy. Mar Environ Res. 46, 295-299; 1998

Quinn, B.; Gagné, F.; Blaise, C. Oxidative metabolism activity in Hydra attenuata exposed to carbamazepine. Fresenius Environ Bull. 13, 783-788; 2004

Smith, J.R.; Fong, P.; Ambrose, R.F. Dramatic declines in mussel bed community diversity: Response to climate change? Ecology 87, 1153-1161; 2006

Smolders, R.; Bervoet, L.; De Coen, W.; Blust, R. Cellular energy allocation in zebra mussels exposed along a pollution gradient: Linking cellular effects to higher levels of biological organization. Environ Poll. 129, 99-112; 2004

Vasseur, P.; Cossu-Leguille, C. Linking molecular interactions to consequent effects of persistent organic pollutants (POPs) upon populations. Chemosphere 62, 1033-1042; 2006

Viarengo, A.; Ponzanon, E.; Donders, F.; Fabbri, R. A simple spectrophotometric method for metallothionein evaluation in marine organisms: An application to Mediterranean and Antarctic molluscs. Mar Environ Res. 44, 69-84; 1997

Wills, E.D. "Evaluation of Lipid Peroxidation in Lipids and Biological Membranes." In: Snell, K., Mullock, B. (eds.), Biochemical Toxicology: A Practical Approach. IRL Press, Washington, USA, pp. 127-150; 1987

Zhu, H.; Banneberg, G.L.; Moldeaus, P.; Shertzer, H.G. Oxidation pathways for the intracellular probe 2',7'-dichlorofluorescin. Arch Toxicol. 68, 582-587; 1994 
Table 1. Region and site geographic characteristics.

\begin{tabular}{|c|c|c|c|c|c|}
\hline Area & Site & $\begin{array}{c}\text { Relative } \\
\text { distance }(\mathrm{km})\end{array}$ & Coordinates & & $\begin{array}{r}\text { Annual } \\
\text { tempera } \\
\left({ }^{\circ} \mathrm{C}\right)\end{array}$ \\
\hline & & West to East & Latitude & Longitude & Meal \\
\hline $\begin{array}{c}\text { Pacific Coast, } \\
\text { British Columbia, } \\
\text { Canada }\end{array}$ & $\begin{array}{c}\text { Hopkins } \\
\text { Landing, B.C. } \\
\text { (reference) } \\
\text { West Vancouver } \\
\text { (Van) } \\
\text { Stanley Park } \\
\text { (Stan) } \\
\end{array}$ & 0 & 49.30 & 123.14 & 10.8 \\
\hline $\begin{array}{c}\text { St. Lawrence } \\
\text { Estuary, } \\
\text { Quebec, Canada }\end{array}$ & $\begin{array}{c}\text { Baude } \\
\text { (reference) } \\
\text { Tadoussac (Tad) } \\
\text { Baie Sainte- } \\
\text { Catherine (Bsc) } \\
\end{array}$ & 5570 & 48.16 & 69.71 & 0.8 \\
\hline $\begin{array}{l}\text { Halifax Bay, } \\
\text { Nova Scotia, } \\
\text { Canada }\end{array}$ & $\begin{array}{c}\text { Terminal pier } \\
\text { (reference) } \\
\text { Marina port (M) } \\
\text { Raw sewage }(\mathrm{E}) \\
\end{array}$ & 6465 & 44.65 & 63.63 & $\overline{6.3}$ \\
\hline $\begin{array}{l}\text { Seine Estuary, } \\
\text { France }\end{array}$ & $\begin{array}{c}\text { YPort } \\
\text { (reference) } \\
\text { Harbour (Har) } \\
\text { Honfleur (Hon) } \\
\end{array}$ & 11000 & 49.27 & 0.106 & $\overline{5.8}$ \\
\hline
\end{tabular}

1. Based on 2005-06 census data (Statistics Canada)

Table 3. Correlation analysis of the biomarkers in blue mussels collected at a large spatial scale.

\begin{tabular}{|c|c|c|c|c|c|c|c|c|c|c|c|c|}
\hline & $\begin{array}{l}\text { Gon } \\
\text { mat }\end{array}$ & $\overline{C F}$ & $\begin{array}{c}\text { ST } \\
\text { index }\end{array}$ & GSI & $\begin{array}{c}\text { Lipid } \\
\mathbf{s}\end{array}$ & $\begin{array}{l}\text { MET } \\
25^{\circ} \mathrm{C}\end{array}$ & $\begin{array}{c}\text { MET } \\
6^{\circ} \mathrm{C}\end{array}$ & $\begin{array}{c}\text { MET } \\
\text { (Temp) }\end{array}$ & GST & $\begin{array}{c}\text { MT } \\
\text { (gills) }\end{array}$ & $\begin{array}{c}\text { MT } \\
\text { (DG) }\end{array}$ & XOR \\
\hline $\begin{array}{c}\text { Gon } \\
\text { mat }\end{array}$ & 1 & $\begin{array}{l}-0.04 \\
\end{array}$ & -0.02 & -0.17 & -0.11 & -0.29 & -0.18 & 0.15 & -0.14 & -0.07 & -0.10 & -0.2 \\
\hline CF & & 1 & $<0.01$ & -0.04 & 0.02 & -0.03 & 0.10 & -0.06 & -0.26 & $<0.001$ & 0.04 & -0.26 \\
\hline $\begin{array}{c}\text { ST } \\
\text { index }\end{array}$ & & & 1 & 0.17 & -0.05 & -0.27 & -0.29 & -0.16 & 0.06 & -0.09 & -0.33 & -0.40 \\
\hline GSI & & & & 1 & 0.2 & -0.18 & -0.23 & 0.06 & -0.21 & 0.08 & 0.09 & 0.04 \\
\hline Lipids & & & & & 1 & 0.15 & 0.06 & 0.12 & $<0.01$ & 0.24 & 0.33 & 0.20 \\
\hline $\begin{array}{l}\text { MET } \\
25^{\circ} \mathrm{C}\end{array}$ & & & & & & 1 & 0.73 & 0.16 & 0.20 & 0.08 & 0.37 & 0.25 \\
\hline
\end{tabular}


Environmental Research 107:201-217. 2008.

\begin{tabular}{|c|c|c|c|c|c|c|}
\hline $\begin{array}{c}\text { MET } \\
6^{\circ} \mathrm{C}\end{array}$ & 1 & -0.01 & 0.04 & $<-0.01$ & 0.17 & 0.10 \\
\hline $\begin{array}{l}\text { MET } \\
\text { Temp }\end{array}$ & & 1 & -0.30 & -0.06 & $\begin{array}{l}0.38 \\
\end{array}$ & 0.28 \\
\hline GST & & & 1 & 0.23 & -0.08 & 0.45 \\
\hline $\begin{array}{c}\text { MT } \\
\text { (gills) }\end{array}$ & & & & 1 & 0.05 & 0.37 \\
\hline $\begin{array}{l}\text { MT } \\
\text { (DG) }\end{array}$ & & & & & 1 & 0.24 \\
\hline XOR & & & & & & 1 \\
\hline $\begin{array}{l}\text { LPO } \\
\text { (gills) }\end{array}$ & & & & & & \\
\hline $\begin{array}{l}\text { LPO } \\
\text { (DG) }\end{array}$ & & & & & & \\
\hline $\begin{array}{c}\text { DNA } \\
\text { (gills) }\end{array}$ & & & & & & \\
\hline $\begin{array}{l}\text { DNA } \\
\text { (DG) }\end{array}$ & & & & & & \\
\hline Vtg & & & & & & \\
\hline $\begin{array}{c}\text { P450 } \\
3 \mathrm{~A}\end{array}$ & & & & & & \\
\hline
\end{tabular}

Abbreviations: gonad maturation index (Gon Mat), condition factor (CF), soft tissue weight ratio (ST), gonado-somatic index (GSI).

Correlation $\mathrm{r}$ values in boldface and italic correspond to $\mathrm{p}<0.05$ and $0.1<\mathrm{p}<0.05$ (marginal) values, respectively. 
Table 2. Data distribution of sites under low pollution impact.

\begin{tabular}{|c|c|c|c|c|c|c|c|}
\hline Biomarker & Mean & $\begin{array}{c}\text { Stand. } \\
\text { deviation }\end{array}$ & Median & Min & Max & $\begin{array}{c}\text { Data } \\
\text { Spred }{ }^{1}\end{array}$ & $\begin{array}{r}\text { Dispe } \\
\text { ind }\end{array}$ \\
\hline $\begin{array}{c}\text { Gonad } \\
\text { Maturation }\end{array}$ & 1.65 & 0.71 & 2 & 1 & 3 & 3 & 2. \\
\hline Condition Factor & 0.18 & 0.06 & 0.18 & 0.08 & 0.27 & 3.4 & 1 \\
\hline Tissue Weight Ratio & 0.43 & 0.09 & 0.41 & 0.31 & 0.65 & 2.1 & 0. \\
\hline GSI & 0.16 & 0.06 & 0.15 & 0.08 & 0.27 & 3.4 & 1. \\
\hline Lipids & 4.03 & 1.1 & 3.77 & 2.1 & 6.7 & 3.1 & 1. \\
\hline MET25 & 0.007 & 0.004 & 0.006 & 0.0006 & 0.0195 & 32 & 2 . \\
\hline MET6 & 0.005 & 0.003 & 0.004 & 0.0007 & 0.011 & 16 & 2 . \\
\hline METT & 0.00015 & 0.0001 & 0.00011 & 0.000018 & 0.000450 & 25 & 2. \\
\hline GST & 0.011 & 0.005 & 0.010 & 0.0024 & 0.020 & 8.3 & $\dot{c}$ \\
\hline Gill MT & 17.9 & 14.8 & 13.5 & 3 & 58 & 19 & $\varepsilon$ \\
\hline DG MT & 17 & 9.5 & 15 & 4.6 & 42 & 9 & 2 . \\
\hline XOR & 41657 & 24714 & 34213 & 7792 & 90089 & 12 & c \\
\hline LPO gill & 9.8 & 6 & 8 & 2.8 & 24 & 9 & $\dot{c}$ \\
\hline LPO dg & 7.9 & 3 & 8.3 & 3 & 14 & 4.7 & 1. \\
\hline DNA gill & 48 & 21 & 44 & 11 & 95 & 9 & 1 1: \\
\hline DNA dg & 19 & 12 & 16 & 2 & 60 & 30 & $\varepsilon$ \\
\hline VTG & 828 & 1000 & 370 & 68 & 5110 & 75 & $\epsilon$ \\
\hline DBF dealkylase & 1390 & 830 & 1260 & 65 & 4454 & 68 & 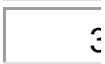 \\
\hline
\end{tabular}

1. Spread was calculated as: maximum value/minimum value.

2. Dispersion index was calculated as follows: (Max-Min)/mean or median

3. Discriminant factor (max-min)/standard deviation

4. Shapiro-Wilk normality test; deviation of normality when $\mathrm{p}<0.05$. 

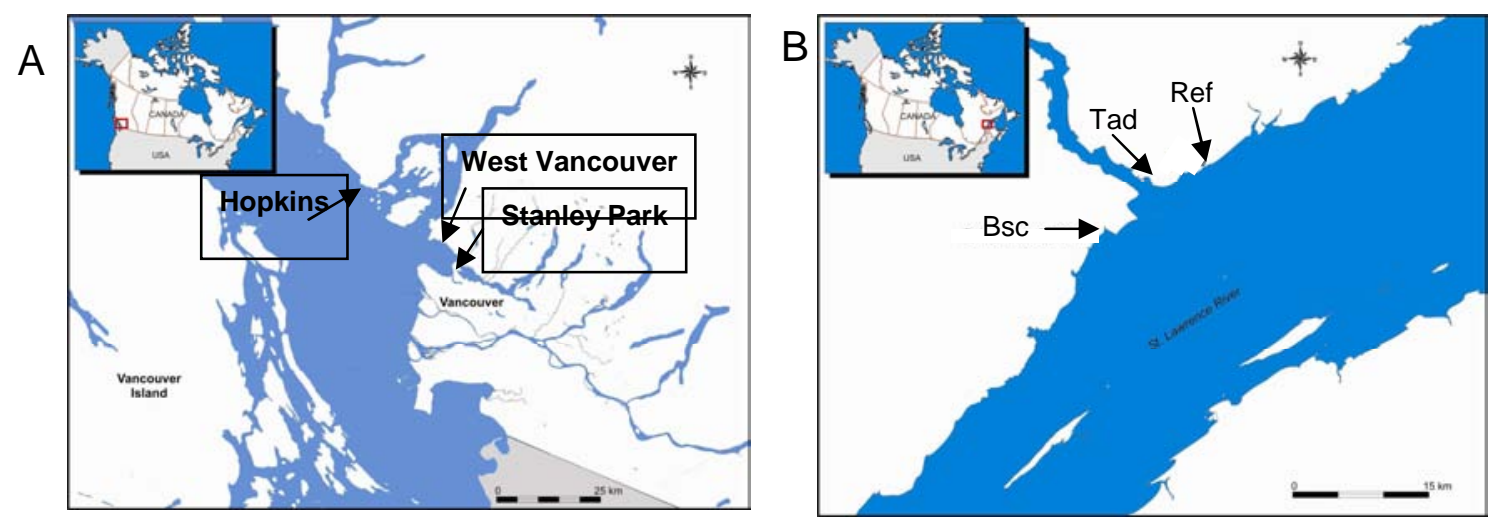

C

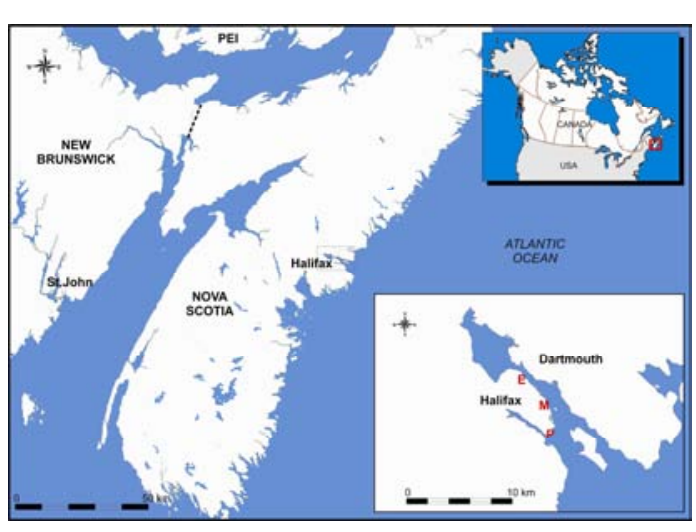

D

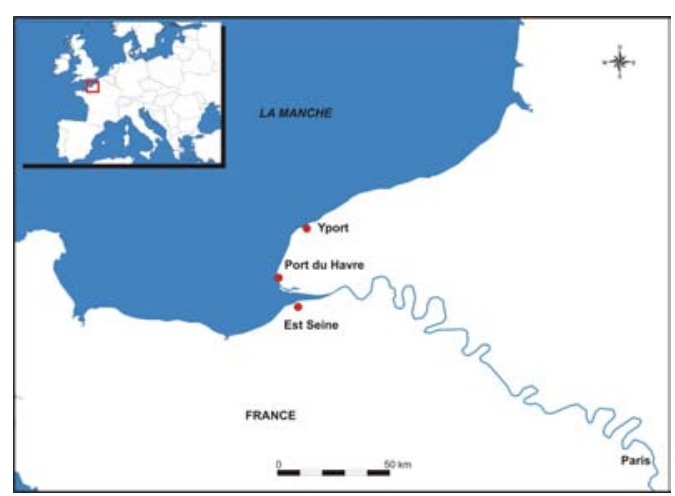

Figure 1. Geographic locations of sampling regions across the Northern Hemisphere.

Four regions were selected, starting from the Pacific West Coast of Canada (A), to the St. Lawrence estuary (B), Halifax Harbour on the Atlantic East Coast (C), and ending with the Seine estuary on the Atlantic west coast of France. 

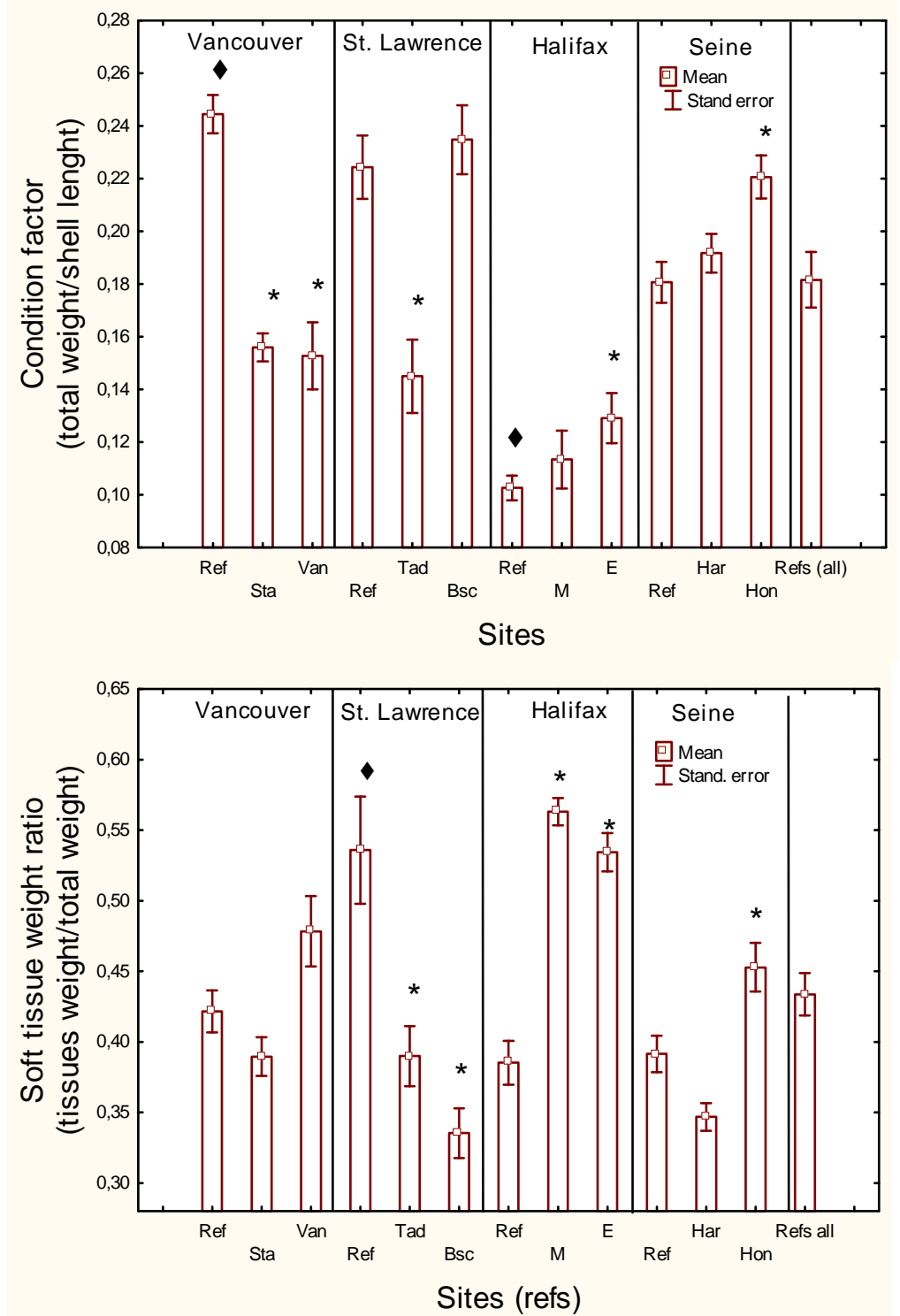

Figure 2 Morphological characteristics of harvested blue mussels.

Mytilus edulis were collected in June 2005 and analyzed for condition factor and soft tissue weight ratio. Asterisks (*) indicate significance in respect to the corresponding regional reference sites and diamond symbols $(\checkmark)$ correspond to significant differences between the mean values of the combined reference sites for each region. 
Environmental Research 107:201-217. 2008.
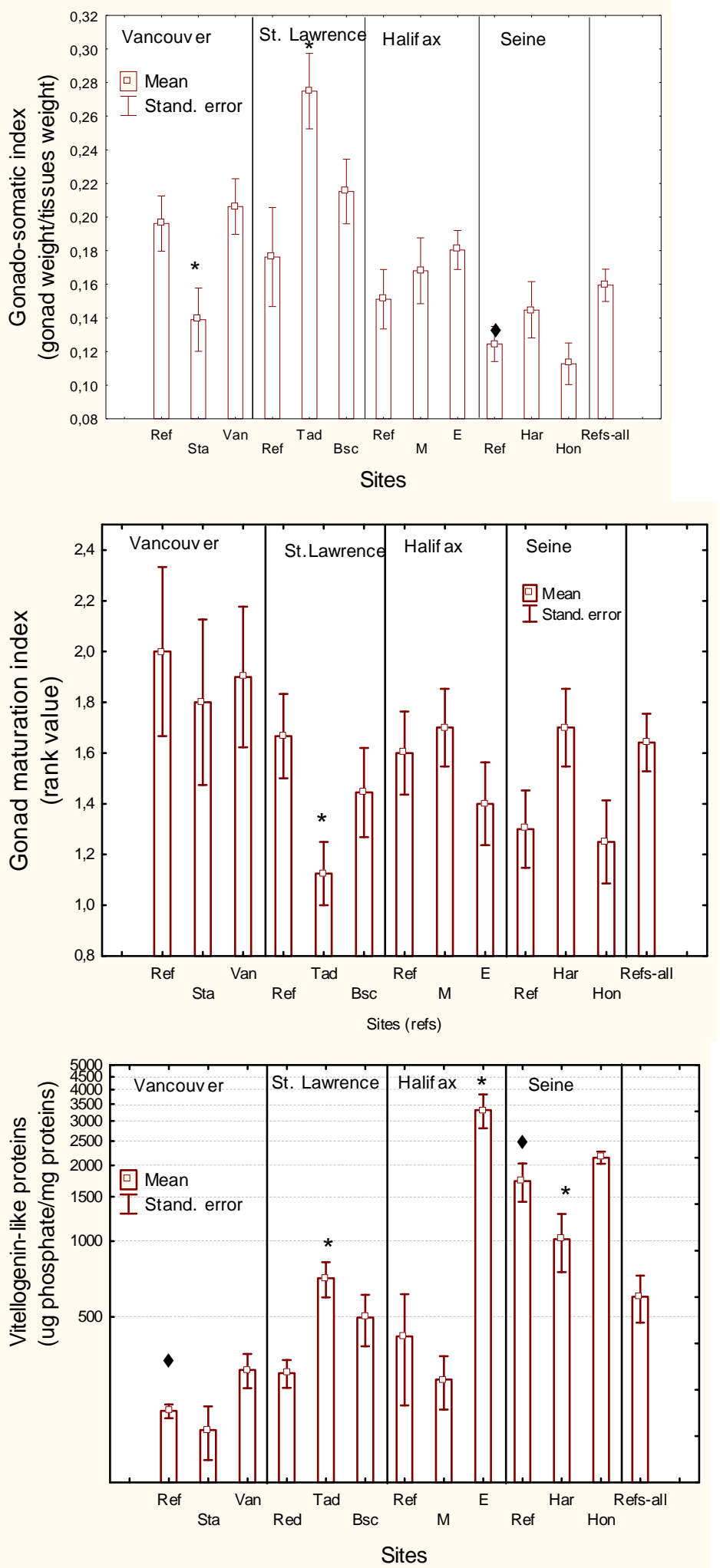
Figure 3 Gametogenic activity of harvested blue mussels.

Mytilus edulis were collected in June 2005 and analyzed for gonado-somatic index, gonad maturation and vitellogenin-like proteins. Asterisks $\left(^{*}\right)$ indicate significance in respect to the corresponding regional reference sites and diamond symbols $(\checkmark)$ correspond to significant differences between the mean values of the combined reference sites for each region. 


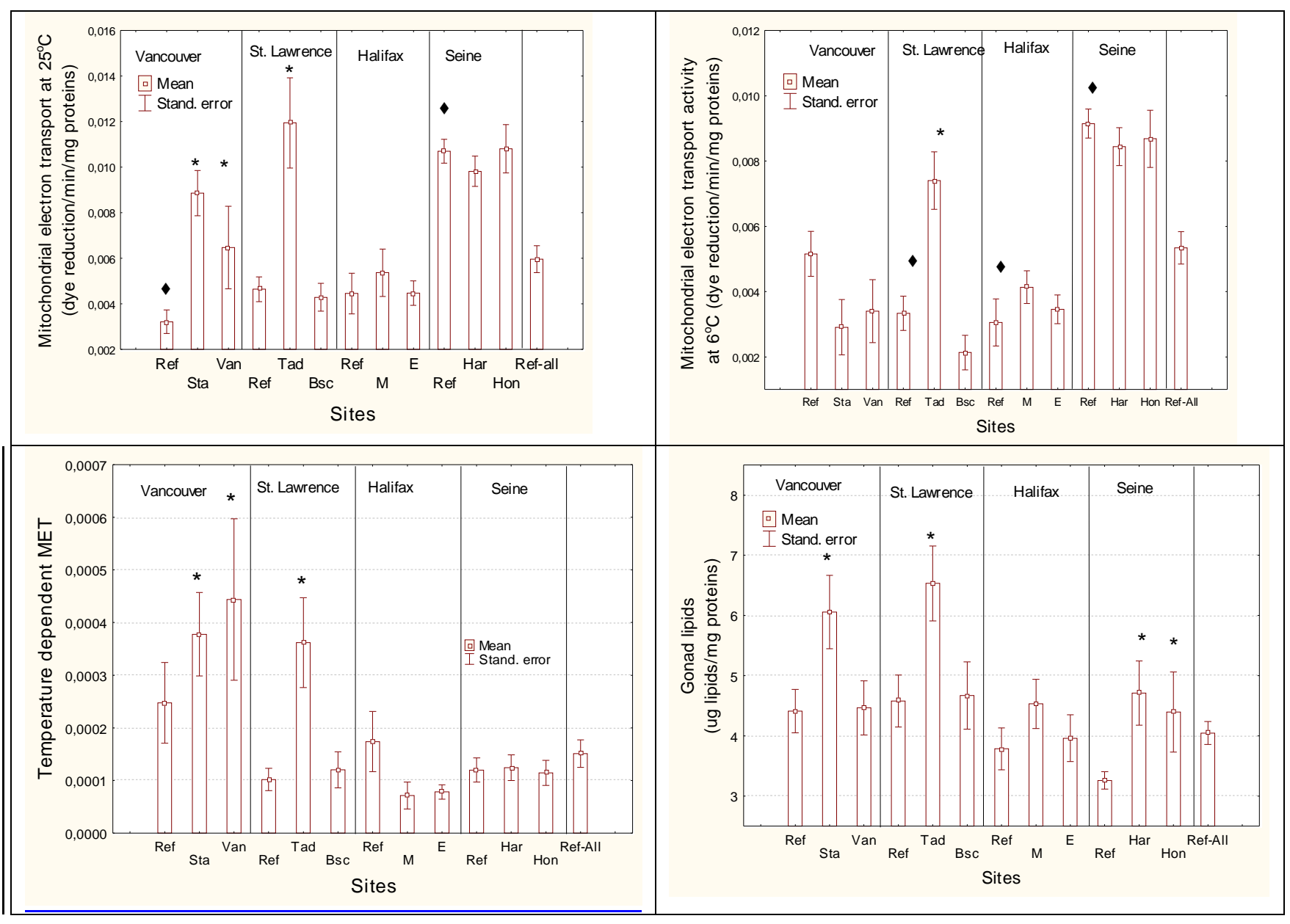

Figure 4 Energy status of harvested blue mussels on a global scale.

Mytilus edulis were collected in June 2005 and analyzed for mitochondrial electron transport (MET) activity at $25^{\circ} \mathrm{C}$ and $6^{\circ} \mathrm{C}$,

temperature-dependent MET and gonadal lipids. Asterisks $\left(^{*}\right)$ indicate significance in respect to the corresponding regional reference 
Environmental Research 107:201-217. 2008.

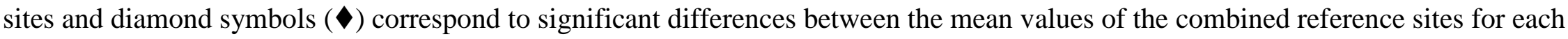
region. 


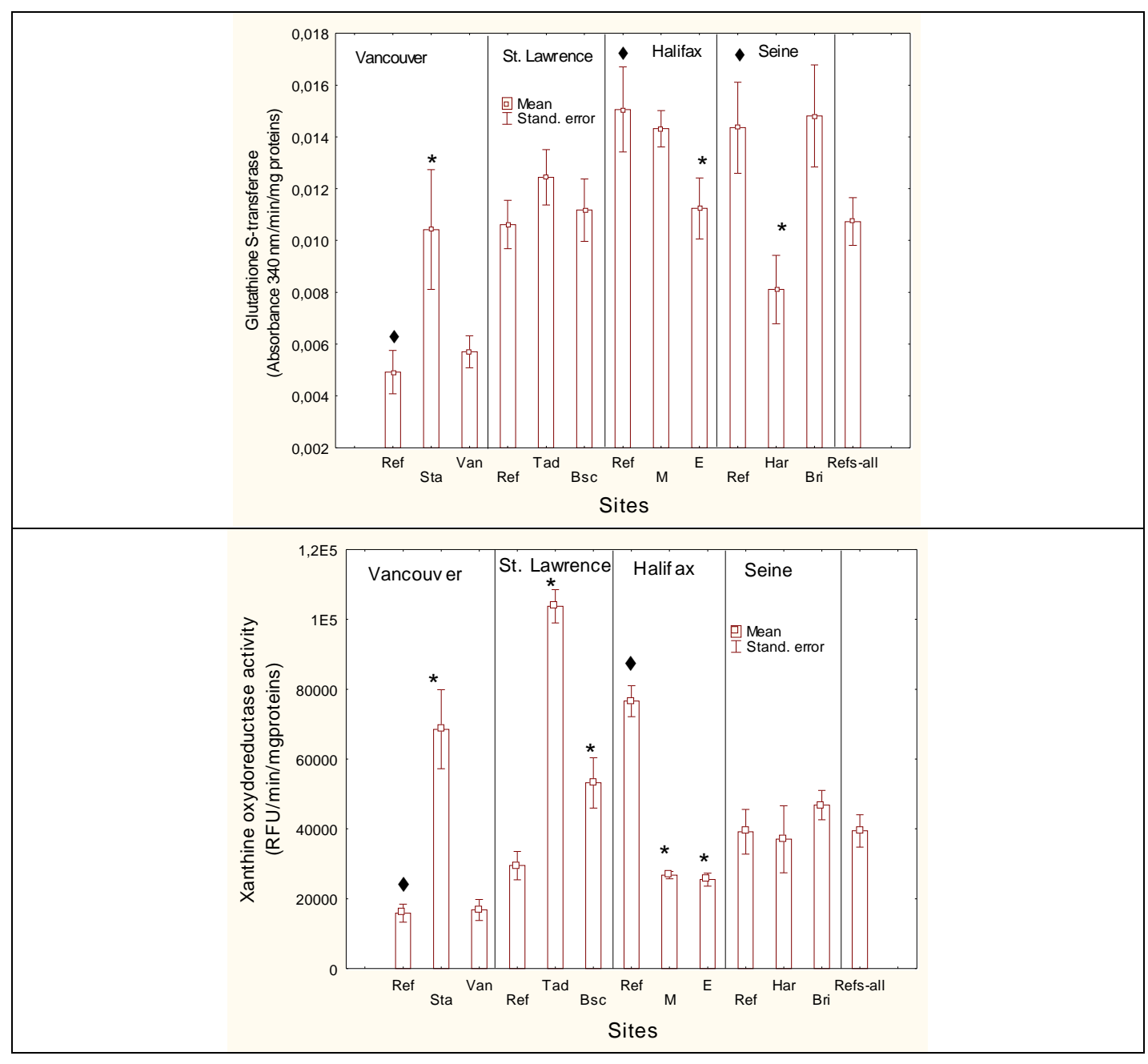




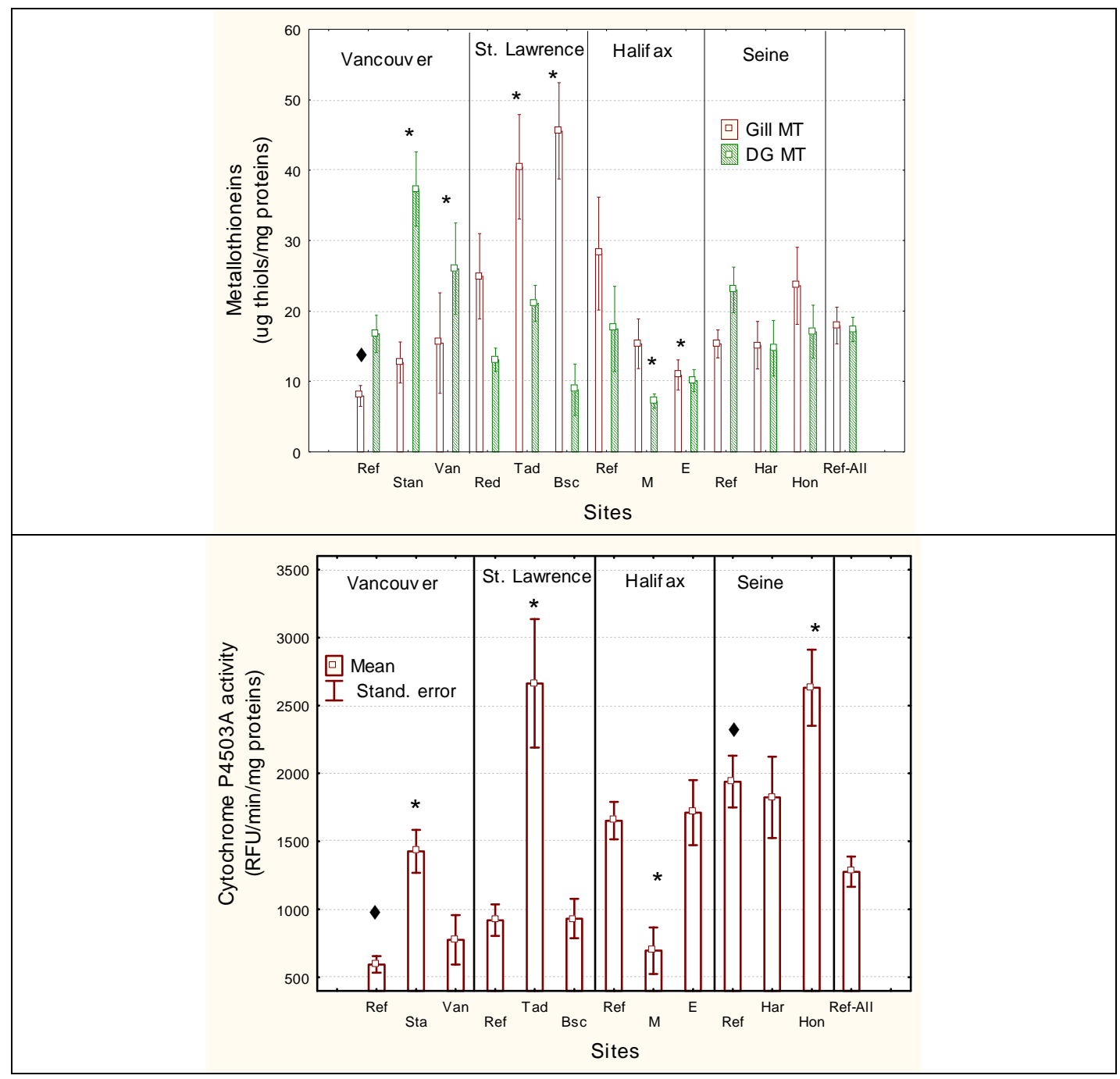


Figure 5 Biomarkers of defense responses in blue mussels collected at various estuaries or bays. Mytilus edulis were collected in June 2005 and analyzed for metallothioneins, glutathione S-transferase activity, mixed-function oxidase and xanthine oxydo-reductase activity. Asterisks (*) indicate significance with respect to the corresponding regional reference sites and diamond symbols ( $)$ correspond to significant differences between the mean values of the combined reference sites for each region. 


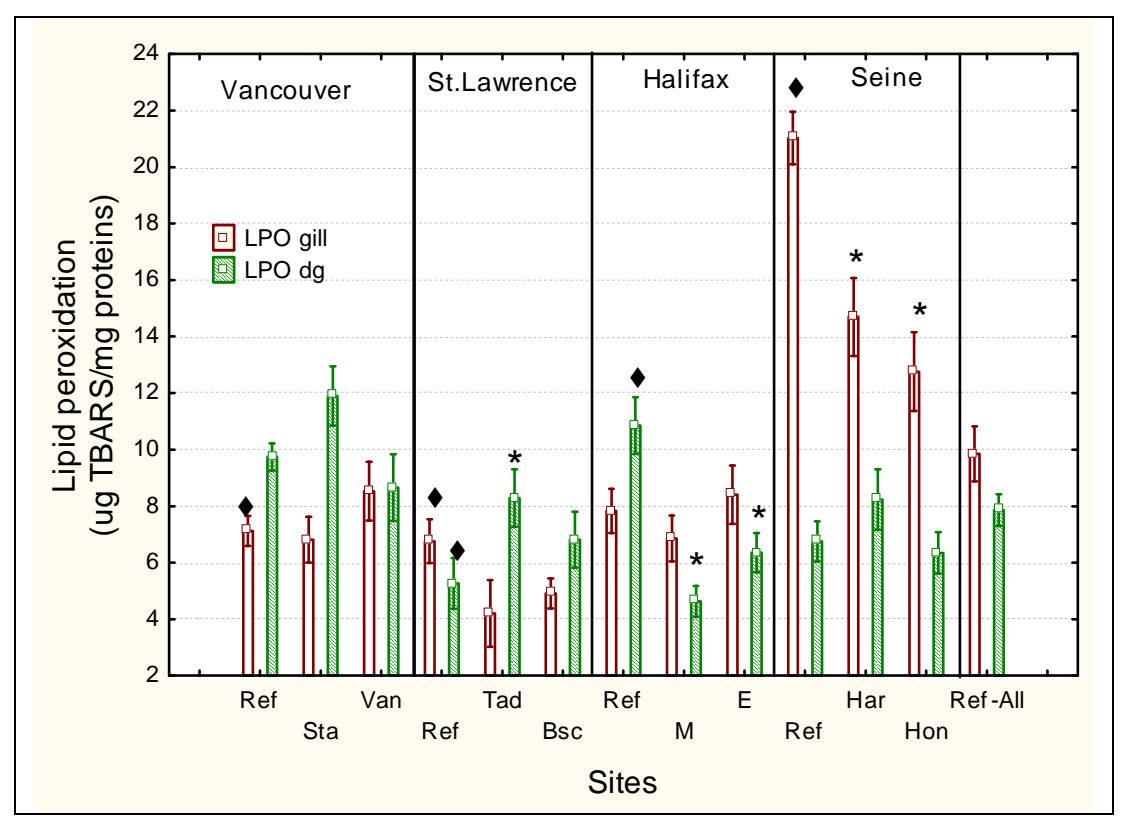




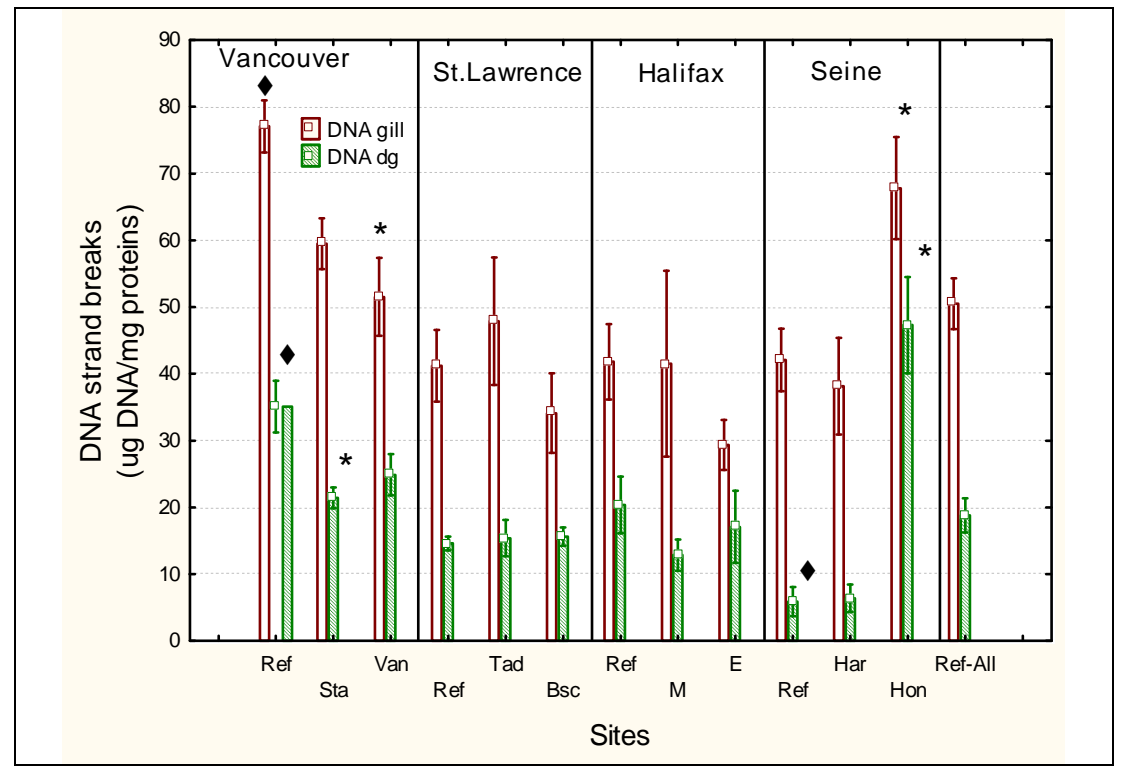

Figure 6 Biomarkers of toxic damage in blue mussels collected at various sites.

Mytilus edulis were collected in June 2005 and analyzed for lipid peroxidation and DNA strand breaks. Asterisks (*) indicate significance with respect to the corresponding regional reference sites and diamond symbols $(\checkmark)$ correspond to significant differences between the mean values of the combined reference sites for each region. 
Environmental Research 107:201-217. 2008

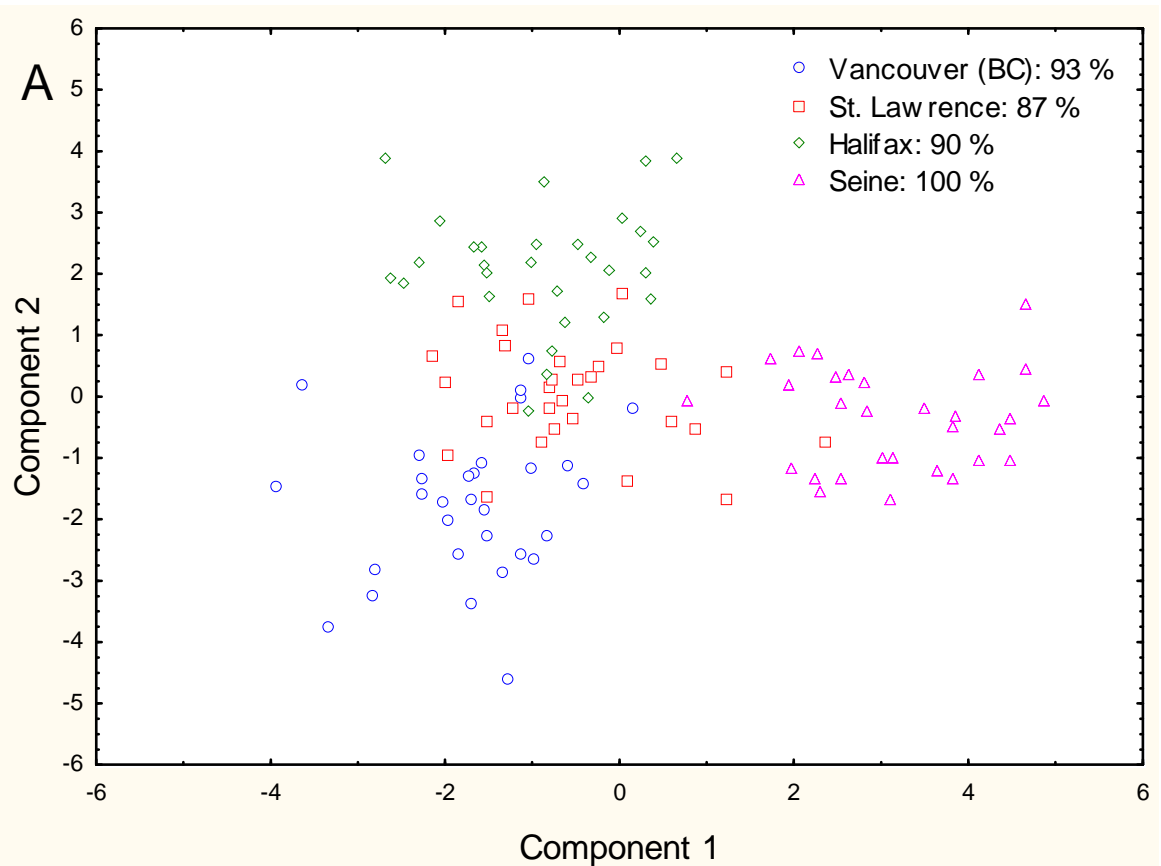




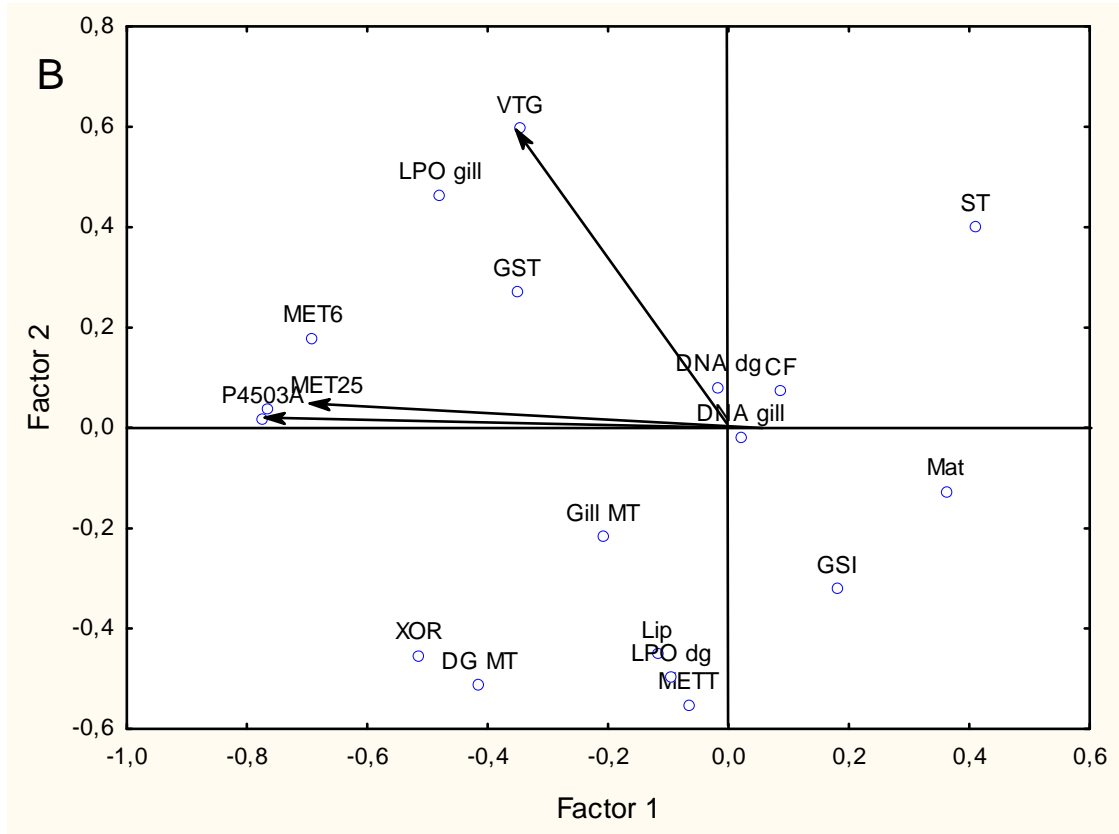

Figure 7. Multivariate analysis of biomarker data across all sites examined.

Biomarker data were submitted to discriminant analysis (A) and factorial analysis (B). 

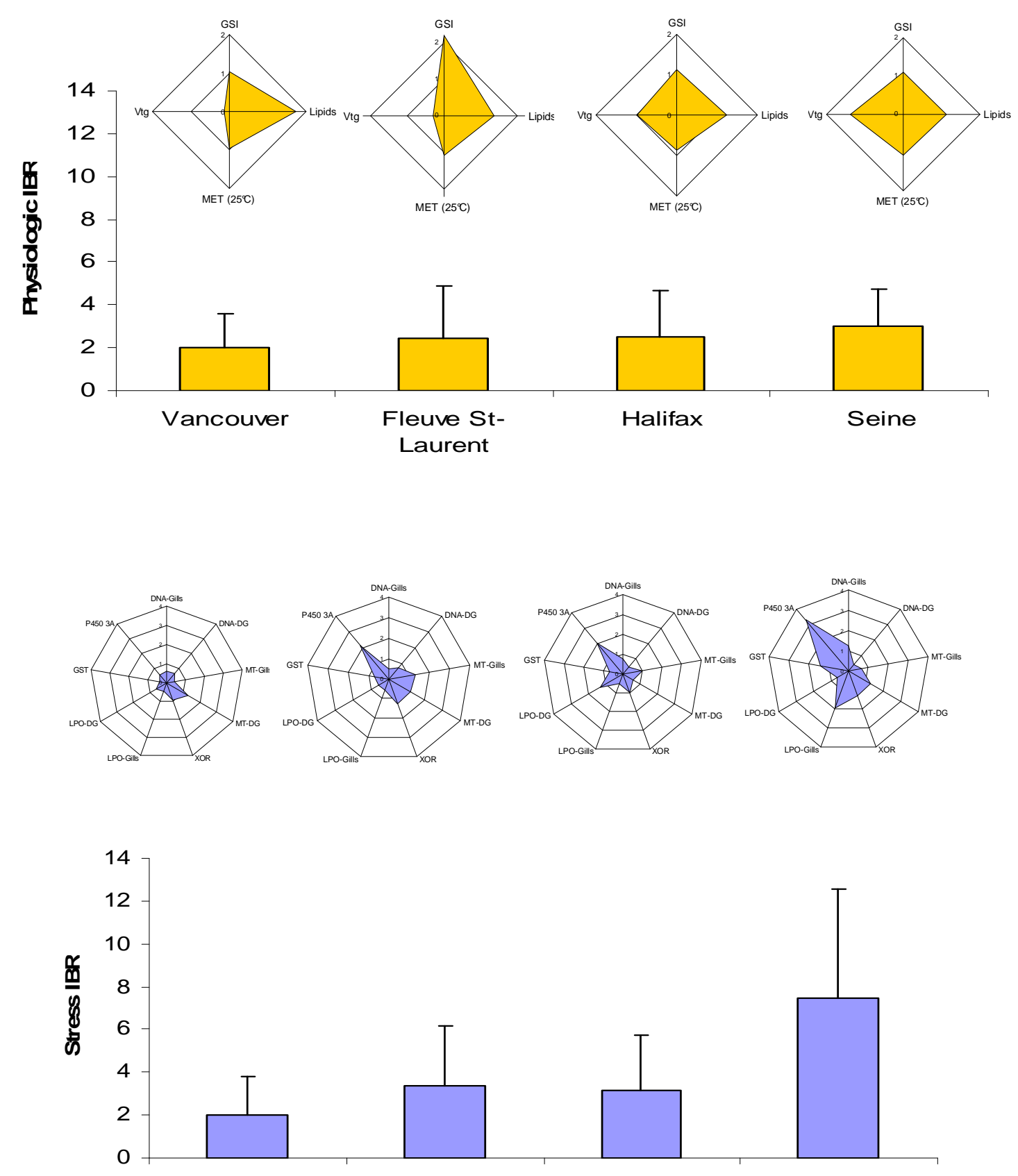
Figure 8. Integration of biomarker responses across the regions

Biomarkers responses were split in physiologic (top) and stress biomarkers (bottom). Physiologic biomarkers were gonadal lipids, vitellogenin-like proteins, the gonado-somatic index and mitochondrial electron transport activity at 25 oC. Stress biomarkers were LPO in gills and digestive gland, MT in gills and digestive gland, DNA damage in gills and digestive gland, cytochrome P4503A-like activity and GST. 